Illinois State University

ISU ReD: Research and eData

Theses and Dissertations

$11-13-2018$

\title{
Translating Le Fresne: Modeling Digital Scholarly Editions
}

Gabrielle Litwiller

Illinois State University, galitwiller@gmail.com

Follow this and additional works at: https://ir.library.illinoisstate.edu/etd

\section{Recommended Citation}

Litwiller, Gabrielle, "Translating Le Fresne: Modeling Digital Scholarly Editions" (2018). Theses and Dissertations. 1025.

https://ir.library.illinoisstate.edu/etd/1025

This Thesis is brought to you for free and open access by ISU ReD: Research and eData. It has been accepted for inclusion in Theses and Dissertations by an authorized administrator of ISU ReD: Research and eData. For more information, please contact ISUReD@ilstu.edu. 


\section{TRANSLATING LE FRESNE: MODELING DIGITAL SCHOLARLY EDITIONS}

\section{Gabrielle Litwiller}

\section{Pages}

With the advancement of technology and the complexity that a digital object can contain, the undergraduate student is able to take steps toward the original document. Through a digital medium, scholarly, editorial, and translational choices can be made explicit to the student and as he/she encounters the text, he/she can also have access to an understanding of elements of methodology and implications predetermined by the scholar. By making the translational choices of the scholar explicit, the digital edition can enable students to become aware of the translational and editorial process. Exposing portions of the translational and editorial process will enable the student to more fully understand, comprehend, and analyze the text, thus moving forward the student's research and scholarship. This project begins with a consideration of digital scholarly editions and commercial digital resources (such as SparkNotes), followed by a discussion of the translation of Le Fresne, by Marie de France. These two discussions are then applied in the creation of a model for digital scholarly editions.

KEYWORDS: Breton lais; digital scholarly editions; Le Fresne; Marie de France; Old French; translation 
TRANSLATING LE FRESNE: MODELING DIGITAL SCHOLARLY EDITIONS

GABRIELLE LITWILLER

A Thesis Submitted in Partial Fulfillment of the Requirements for the Degree of

MASTER OF ARTS

Department of English

ILLINOIS STATE UNIVERSITY

2018 
Copyright 2018 Gabrielle Litwiller 
TRANSLATING LE FRESNE: MODELING DIGITAL SCHOLARLY EDITIONS

GABRIELLE LITWILLER

COMMITTEE MEMBERS:

Susan M. Kim, Chair

Katherine Ellison 


\section{ACKNOWLEDGMENTS}

I would like to thank my advisors, Dr. Susan M. Kim and Dr. Katherine Ellison, for their patient guidance throughout this project. I would also like to thank: my brother Jake for his technological wisdom; my officemate, Becca, for her kinship; my mother, Debbie, for her continual enthusiasm for my work; and my husband, Josh, for his constant encouragement.

G. L. 


\section{CONTENTS}

Page

ACKNOWLEDGMENTS

$\begin{array}{ll}\text { CONTENTS } & \text { ii }\end{array}$

TABLES $\quad$ iv

FIGURES

CHAPTER I: INTRODUCTION 1

CHAPTER II: DIGITAL TEXTS AND THE STUDENT 6

$\begin{array}{ll}\text { Introduction } & 6\end{array}$

Analysis of Electronic Beowulf $\quad 8$

Analysis of Piers Plowman Electronic Archive 17

$\begin{array}{ll}\text { Commercial Digital Resources } & 19\end{array}$

$\begin{array}{ll}\text { Conclusion } & 28\end{array}$

CHAPTER III: TRANSLATORS OF LE FRESNE 30

$\begin{array}{ll}\text { Textual History } & 30\end{array}$

Breton Lais $\quad 35$

$\begin{array}{ll}\text { Artifacts } & 40\end{array}$

$\begin{array}{ll}\text { Translating Le Fresne } & 42\end{array}$

Collaborative Translators 53

$\begin{array}{ll}\text { CHAPTER IV: A MODEL } & 57\end{array}$

$\begin{array}{ll}\text { Introduction } & 57\end{array}$

$\begin{array}{ll}\text { The Model } & 60\end{array}$

$\begin{array}{ll}\text { Conclusion } & 69\end{array}$ 
$\begin{array}{ll}\text { REFERENCES } & 73\end{array}$

APPENDIX A: MANUSCRIPTS OF LE FRESNE

APPENDIX B: SURVEY DATA $\quad 82$

APPENDIX C: SURVEY REFERENCES 


\section{TABLES}

Table

Page

1. Quantcast Ranks for Digital Commercial Resources as of 9 Feb. 2018 


\section{FIGURES}

Figure

Page

1. Example of Backlit Use to See Text Underneath the Paper Frame 11

2. Example of PPEA "Passus M.8” Page Remarking on Unique Aspects of the Text 12

3. Example of PPEA "Passus M.8” Coding File for Par in Line 11

4. Example of PPEA "Passus M.8” Page Displaying the TEI Tags for Lines 8-13 14

5. Sample Screenshot of Multiple Tools Open on EB 16

6. Sample Rendering of the Middle English Script as Found on the PPEA 18

7. A Character Map for Beowulf Created by CliffsNotes 26

8. Canterbury Tales with a Side Banner for the SparkNotes Blog 27

9. An Image of the "Welcome" page, Demonstrating the Design and Layout of the Model 60

10. The TEI Code for Lines 121-126 64

11. The TEI Code for the Parsing of Un 64

12. The Model as Seen on a Pixel 2 Phone 67

13. The Model as Seen on a Pixel 2 Phone with Rendering Flaw 68

14. The Language and Revision Description of the TEI Code 69 


\section{CHAPTER I: INTRODUCTION}

This thesis will explore and endeavor to understand digital editions and the advancement of translational work for undergraduate students. Medieval manuscripts (rare, in odd writing styles, and old languages with no standardized spelling) are inherently inaccessible to students. Because of this, scholars transcribe, edit, and translate the manuscripts, putting them into familiar forms for modern readers. Scholars have worked diligently to equip critical translations with historical, cultural, textual, and linguistic aids, which all permit the student to understand the text with a level of comprehension closer to that of a scholar. Now, with the advancement of technology and the complexity that a digital object can contain, the undergraduate student is able to take steps toward the original document. Through a digital medium, scholarly, editorial, and translational choices can be made explicit to the student and as he/she encounters the text, he/she can also have access to an understanding of elements of methodology and implications predetermined by the scholar. By making the translational choices of the scholar explicit, the digital edition can enable students to become aware of the translational and editorial process. Exposing portions of the translational and editorial process will enable the student to more fully understand, comprehend, and analyze the text, thus moving forward the student's research and scholarship.

This introductory chapter describes and outlines the structure of the following chapters. The second chapter is concerned with digital scholarly editions and discusses the use of digital resources by students. The following chapter takes a close look at Le Fresne, by Marie de France, and considers the workings of translation within and without the text. A model is described in chapter four, which applies the information and research gained from the previous 
two chapters. The thesis concludes with chapter five and considers the broad concept of translation and interpretation.

The second chapter provides a context for digital scholarly editions of medieval texts and an analysis with the guidance of the MLA Statement on the Scholarly Edition in the Digital Age (2015), written by MLA Committee on Scholarly Editions (MLA-CSE). The MLA-CSE recognizes the continual evolution of editions, especially the digital ones, and so seeks to reestablish definitions of "editions" that will continue to enable "the ability to recognize excellence and failure" of them (6). The statement concludes with a set of minimal conditions for scholarly editions. This asks for the transparent reasoning of various choices and approaches taken or avoided in the production of the edition, along with attention to thoroughness and accuracy expected of scholarly editions. Additional parameters for specifically digital editions are also stated. The scholarly and digital considerations are laid out at the beginning of chapter two. The guidelines are concise and endeavor to be broad enough to encompass the inevitable advancements and evolution of scholarly editions.

To better understand the MLA guidelines, I analyze the Electronic Beowulf (EB) and Piers Plowman Electronic Archive (PPEA). The EB, in its fourth edition, has been available since 1999 (the fourth edition came out in 2015), and is open to the public. The purpose of the edition is:

To meet the needs of general readers, who require a full, line by line, translation; of students, who want to understand the grammar and the meter and still have time in a semester to study and appreciate other important aspects of the poem; and of scholars, who want immediate access to a critical apparatus identifying the nearly 2000 eighteenth- 
century restorations, editorial emendations, and manuscript-based conjectural restorations. (Kiernan and Iacob)

PPEA has a similar goal: "The Archive enables instructors, students, and researchers to explore late medieval literary and manuscript culture through the many variations of Piers Plowman. The long-term goal of the project is the creation of a complete archive of the medieval and early modern textual tradition of Langland's poem." This archive seeks to engage each possible reader, from high school students to "historians, historical linguists, dialectologists, literary historians, [and] paleographers" (Duggan et al.). Both the EB and PPEA appeal to student and scholar.

Because I am interested in student use of digital editions, I surveyed the perceived use of SparkNotes and CliffsNotes and their free resources. These are two popular sites that appeal specifically to students. In surveying them, I wish to understand how students use particular tools provided by the sites (such as quizzes, summaries, and sample analyses) to comprehend and study literature. I believe this information is important to consider when designing digital scholarly editions that are meant to be used in the classroom.

The third chapter considers Le Fresne, by Marie de France (composed between 1155 to 1200), as a text encompassed with translation. Le Fresne was translated from Anglo-Norman to Old French, Old Norse, and Middle English in its early history. ${ }^{1}$ This $l a i^{2}$ also illustrates translation within the text as the central character, Le Fresne, moves throughout the narrative. Le Fresne is translated by the other characters after they interpret the three objects associated with

\footnotetext{
${ }^{1}$ See appendix A for a description of manuscripts.

${ }^{2}$ I have chosen to use the French spelling lai and lais instead of the English spelling lay and lays because it reflects the historical context that I am working within.
} 
her: a ring, a silk cloth, and an ash-tree. Her narrative trajectory is impacted by the interpretation of these objects by the other characters. This understanding of the use of objects to translate can also be seen as the manuscript is translated.

For instance, when translating and editing the text modern translators must consider the following: whether to keep the poem in lines or switch to a rhythmic prose; whether to follow a rhyming schema; whether to choose English words which match the specific definition of the Old French words or match the new words with the emotion of the context, etc. Other considerations include the following questions: will scenes be cut, or descriptions added to; will cultural traditions be explained, or will they change to match the new culture; etc.? Each of these decisions arises minutely in its single occurrence, but the use of them across a text will broaden and expand the text in new ways. All of these choices, like the objects by which the character Le Fresne is interpreted, create a set of lenses through which the narrative as a whole may be interpreted.

With each new translation and edition of Le Fresne, a new collection of collaborating authors is brought in. To illustrate collaborative writing, I highlight Lukas Erne's work, Shakespeare's Modern Collaborators (2008), which considers the collaborative authors of Shakespeare. Erne lays out the four specific areas of collaboration present in Shakespeare's work, ending with modern editors as collaborators, "the people who prepare the texts we read in modern editions" (3). Though written centuries earlier than Shakespeare's works, Le Fresne also has a similar trail of authors: those who orally recited the story, Marie who wrote it down, later translators, and modern translators and editors. Each of these individuals and communities gives shape to the story based on their interpretation and understanding of the text and its original culture. 
After considering digital scholarly work in chapter two and an analysis of Le Fresne in chapter three, I implement the research gained by creating my own model of a digital scholarly edition of Le Fresne. In chapter four I explain the decisions and considerations for the implementation of the standards of the MLA-CSE in the model. I have coded the model with TEI, HTML, JavaScript, and jQuery, and include a brief textual, editorial, and critical introduction. The model is designed to be interactive, allowing viewers to construct their own translation of Le Fresne based on the parsing information provided. As this is a model, the whole lai is not presented and instead lines 121 through 126 are given. This passage is the first description of the ring and silk cloth, occurring when the mother gives them to Le Fresne before abandoning her. Though interacting with this small digital edition, which focuses on translational aspects, will not expose viewers to all translational issues and concepts, it will provide a small window into these concepts and allow them to take part in the process.

The final chapter concludes by considering the multiple instances of translation and interpretation found throughout this project. It also highlights the need for continued study in understanding the use of digital editions and resources by students so to better build future digital scholarly editions. 


\section{CHAPTER II: DIGITAL TEXTS AND THE STUDENT}

\section{Introduction}

In this chapter I will be discussing the features of digital editions, focusing on those of medieval texts specifically. I will consider digital scholarly editions, along with commercial digital resources (for instance, SparkNotes and GradeSaver), which are popular among students. One specific tool I will be using to analyze the scholarly editions is the MLA Statement on the Scholarly Edition in the Digital Age (2015) written by the MLA Committee on Scholarly Editions (MLA-CSE).

The MLA Statement outlines "minimal conditions that mark an edition as a scholarly edition and identifies further conditions that apply specifically to a digital scholarly edition" (1). To do this the MLA-CSE first sets out to define "digital," "scholarly," and "edition." I have included the eight minimal conditions for a scholarly edition, as well as the digital criteria, as proposed by the MLA-CSE below, as I will refer to the list throughout. To be a scholarly edition:

1. It must account completely and responsibly for the textual landscape it represents;

2. It must fully describe and justify its editorial methods;

3. It should reveal the processes by which it was created and disseminated (including data, data structures and constraints, and algorithmic or dynamic processes), and it should include a record of changes and updates made to the edition over time, which otherwise tend to remain invisible in the digital environment;

4. It should reveal the judgment and scholarship, the editorial rationales and processes, on which the edition is based;

5. It should evince a rigorous standard of accuracy and consistency in applying a particular editorial approach, set of theoretical premises, or method; 
6. It should demonstrate the appropriate fit among stated methodology, stated goals of the edition (reconstructing authorial intent, reconstructing the social text, etc.), and the nature of the existing textual witnesses;

7. It should contain a detailed textual introduction or editorial policy statement, as distinguished from a critical introduction, that outlines these aspects; and

8. It should include consideration of how the edition can circulate and function as a scholarly resource over time. (7)

To be a digital scholarly edition (and including the above concerns):

1. It must note its technological choices and be aware of their implications, ideally using technologies appropriate to the goals of the edition (see fit between methods and goals, above), in recognition of the fact that technologies and methods are interrelated in that no technical decisions are innocent of methodological implications and vice versa;

2. It should be created and presented in ways ensuring the greatest chance of longevity - addressing this challenge involves infrastructural, financial, and data representation issues (such as the use of widely accepted, open standards);

3. It should readily respond to the challenge of maintaining the scholarly ability to be referenced in view of the ways that interfaces such change over time; and

4. Where possible, it should attend to possibilities of sampling, reuse, and remix, supporting approaches to the formation and curation of the edition such as reconstructing and documenting instances of texts and textual change over time, like algorithmic construction and reconstruction (with possible extensibility, including external data); in doing so, it should attempt to balance considerations 
for intellectual property and labor with the goals of achieving open access and reusability. (7-8)

Essentially, the MLA-CSE is asking for a detailed explanation of the decisions that went into creating the edition. It will be helpful to have a notion of the standards laid out by the MLA-CSE for discussion in this chapter as well as chapter four.

\section{Analysis of Electronic Beowulf}

Kevin Kiernan, the editor of Electronic Beowulf, received his graduate degrees in medieval studies at Case Western Reserve University. Kiernan's entire career was spent at the University of Kentucky, where he specialized in Old and Middle English language and literature, along with digital humanities. He has several awards, and in 1992 he founded the Collaboratory for Research in Computing for Humanities, "which provides infrastructure and support for faculty undertaking projects in the digital humanities” (“Kevin Kiernan”). Kiernan’s initial research was focused on the dating of Beowulf (Beowulf and the Beowulf Manuscripts, published in 1981). This research prompted the British Library to request a digital edition of his work, leading to the advent of the Electronic Beowulf project in 1993. The library's program, Initiative for Access, worked with Kiernan and Paul Szarmach (Western Michigan University) to design the edition (Wisdom). The Initiative for Access was one of the first digitization and web development programs at the British Library.

The Electronic Beowulf (EB) was first published as a CD-ROM in 1999, though the project began in 1993, and is currently in its fourth edition (published in 2015) (Kiernan et al.; Simpson par 1). Emil Iacob programmed the text with Java and HTML, which, during a time of technological influx and transition, made EB a long-lasting resource. As time went on, the 
coding structure initially used by EB became the mainstream structure and thus did not require specialized coding to view. Initially Java was a smart choice, but as seen with the third edition, the language would need updating to adjust to Java's new security codes. The EB went from CDROM to DVD, and in 2015 it was posted to the web with JavaScript (Copland et al.; Kiernan et al.).

Kiernan states the purpose of the edition on the website:

The online edition is designed to meet the needs of general readers, who require a full, line by line, translation; of students, who want to understand the grammar and the meter and still have time in a semester to study and appreciate other important aspects of the poem; and of scholars, who want immediate access to a critical apparatus identifying the nearly 2000 eighteenth-century restorations, editorial emendations, and manuscript-based conjectural restorations. (Kiernan et al.)

Copland et al., in their 2016 review, emphasize that the intention of the edition is not to encapsulate the entire discourse of a particular theory or methodology in the study of Beowulf. They suggest, "The most important thing about EB 4.0, as with its predecessor editions, is that it is intended to function as a companion to and tool for the study of Beowulf rather than a summa of contemporary textual, linguistic, and literary thought on the poem" (Copland et al. par. 12). EB provides introductory information of the manuscripts at a depth that can be utilized by multiple disciplines but does not explain the specific focus that it emphasizes by way of an introduction. Including information on the guiding theories would aide in understanding the assumptions taken about the text, which are thus influencing the content of the edition (this concerns point seven of the MLA Statement). Copland et al. make note of the bibliography: 
The bibliographic context Kiernan provides is both very informal (no works are actually cited) and includes the name of only one of the editors whose specific emendations are being challenged. When the Guide [a webpage with a short description of the site] does provide context, it tends to be by reference to Kiernan's own previous writing, collected in what appears to be an informal post-print repository on a personal university webspace. (Copland et al. pars. 17-18)

Additional texts that would prove helpful in better understanding this edition include the sources consulted for the definitions. A short description of what Kiernan is intentionally not doing could also be helpful and would give further context to the edition. Kiernan briefly describes the textual and digital history of the Thorkelin A and B, Conybeare, and Madden texts but does not explain their importance to this project or how these texts fit into the greater apparatus of Beowulf. Though the MLA-CSE does not explicitly request a bibliography, it can be implied in the recognition of the textual landscape (point one above).

However, EB does provide information about the coding choices, specifically revisions as it changed platforms and explains the restorative technologies used to create the high-quality images, including conjectural restoration, infrared, ultraviolet, fiber-optic backlighting (see figure 1 for example images). 


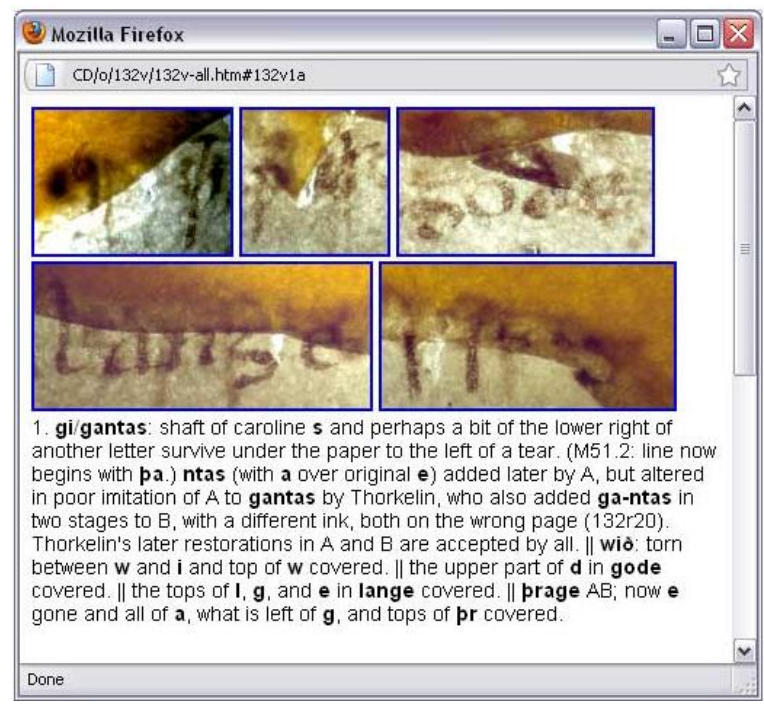

Figure 1. Example of backlit use to see text underneath the paper frame (Kiernan and Iacob figure 13)

Though the bibliography is lacking, the detailed images and textual notes are excellent; "These notes are a considerable achievement and represent perhaps the greatest value in the edition for a scholar of the poem," Copland et al. notes (par 26). Though Kiernan is not explicit about his methods, there is evidence of rigorous accuracy and consistency in his approach (this addresses the fifth concern of the MLA Statement).

As we move to a digital understanding of the edition, EB maintains the standards set by the MLA-CSE. It shares a brief technological history, explaining its reasoning for the latest edition mediums (namely moving from DVD to the web), which addressed its longevity, and the reusability of the edition is found in its free access.

Though longevity is addressed and the use of HTML in the original creation allowed for longer accessibility, TEI (Text Encoding Initiative), not HTML (Hypertext Markup Language), is considered a superior coding language among scholarly editions. TEI was first articulated at a 
meeting at Vassar College in 1987. Scholars sought the expansion of the humanities in the digital context, but as digital technologies were being developed in the late twentieth century the need for a standard methodology amongst the humanities was realized. May 1994 saw the first official version of TEI guidelines released, with several drafts following between 1990-1993, while the latest, P5 version, was released in November 2007 (“TEI: History”). TEI is a custom XML markup language. This is the coding language of choice for digital scholarly editions in the humanities and has been endorsed by "the US National Endowment for the Humanities, the UK's Arts and Humanities Research Board, the Modern Language Association, the European Union's Expert Advisory Group for Language Engineering Standards, and many other agencies around the world that fund or promote digital library and electronic text projects" ("TEI: History"). This markup language is used to record the unique features of texts, including marginal notes and erasures, aspects that do not transcribe well (see figure 2 for a rendered example of TEI and figure 3 for a coding tree example).

\begin{tabular}{|c|c|}
\hline & $\{\ldots \ldots\}^{C}$ \\
\hline prima de dowell $\mathbf{C}$ & $\begin{array}{l}\text { M.8.0: Something, no } \\
\text { longer legible, is } \\
\text { erased in the right } \\
\text { margin. }\end{array}$ \\
\hline \multicolumn{2}{|l|}{ romede aboute } \\
\hline \multicolumn{2}{|l|}{ lowell } \\
\hline \multicolumn{2}{|l|}{ t I mette } \\
\hline $\begin{array}{l}\text { Dowel was at innfne } \\
\text { many folk }{ }^{\mathrm{T}} \text { I ax\{...\}ede }\end{array}$ & $\begin{array}{l}\text { \# the questioun askyn of } \\
\text { Freris of dowell }\end{array}$ \\
\hline
\end{tabular}

Figure 2. Example of PPEA "Passus M.8" page remarking on unique aspects of the text:

"Something, no longer legible, is erased in the right margin" 


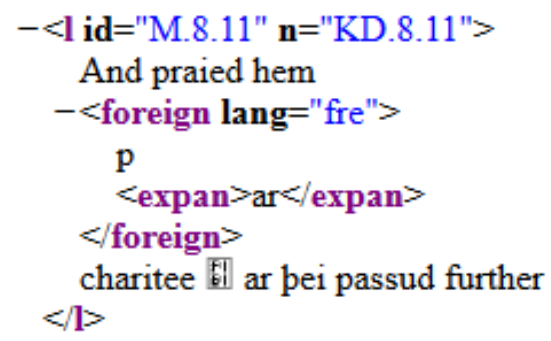

Figure 3. Example of PPEA "Passus M.8" coding file for par in line 11

TEI is a markup language that describes the text, "representing the structural, renditional, and conceptual features of texts" ("TEI: Guidelines"). PPEA offers a setting to display the TEI tags. As seen in figure 4 below, the TEI is providing data on the poem. The $<1>$ or line tag communicates that these are line segments in contrast to paragraphs. As seen in the first line below, a popup box is interrupting the line and is presenting the line across two lines, but the line tags communicate that line eight extends till the word mette even though the line is visually broken. Rhyming is another feature of a poem that can be described in TEI (see figure 10 in chapter four for an example of this). PPEA also uses TEI to denote foreign words. Par, in line eleven, is noted as a foreign word; however, this notation is only shown in the TEI (see figure 3). In the initial rendering of the page, there is no additional description to explain to viewers that the word is foreign, though it is displayed in italics hinting at its uniqueness. The TEI coding tree (as seen in figure 3) denotes par as a French word with the language class "fre." TEI defines for the computer program features of a text that humans readily see and understand, such as lines, line breaks, rhyming, alliteration, stanzas, etc. All of these features must be defined for digital programs. Thus, TEI arose to create a standardized way of defining this information. This 


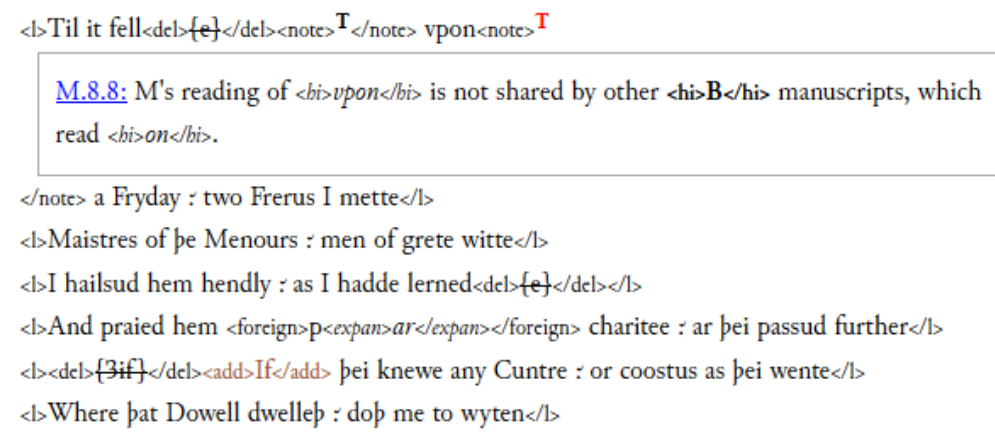

Figure 4. Example of PPEA "Passus M.8" page displaying the TEI tags for lines 8-13

standardization makes it easier to share and understand digital work. TEI gives data on the literature, whereas HTML is used primarily to render information and not provide it. PPEA contains TEI but is expressed and displayed with HTML. For example, HTML divides the page into different sections (for instance, the poem is centered, with line numbers and notes in the right and left margin, partially seen in figure 2). Both HTML and TEI are used to create PPEA but having TEI allows for a special marking of the text, something which would be difficult to do and to standardize with HTML alone.

The use of TEI in EB would also have addressed Copland's et al. concerns for an accessible structure so that researchers can, "modif[y] or supple[ment] it to explore different research questions the editor has not already thought of" (Copland et al. par. 42). "A TEI-based edition could have had rich information about the poem encoded directly into the text of the edition in a format that others could have mined and made use of in ways not explicitly accounted for by the editor," according to Grant Leyton Simpson, who reviewed the DVD 3.0 
edition in 2013 (though it was released in 2011) (Simpson par. 4). Simpson was primarily concerned with the interface of the edition. He also wished that TEI had been the coding language and noted the choice of HTML as a "missed opportunity" (Simpson par. 4). The final concern of Copland et al. regarding the markup language is continued usability and reusability of the digital edition, which requires constant upkeep. Though it worked in the early nineties, coding languages have evolved and standardized, leaving custom builds, such as the one used in EB, hindering future longevity of editions (Copland et al. par. 47). The main reason for persisting problems with this edition is "its long-standing position as a pioneer in the field" and the "decisions made in putting the edition together for its original publication 1999" (Copland et al. par. 56). Though the edition needs updating within its foundation, the work that it did in the new field of digital humanities should still be recognized.

In the review Copland et al. also gathered information on their students' use of the edition: "Our class's work with the edition in the Spring of 2016 demonstrated that, sixteen years on, the Electronic Beowulf remains a useful complement to standard critical texts for the study of Beowulf in Old English. It is relatively easy to use, attractively presented, and it contains many tools that students in particular found helpful for in their studies" (Copland et al. par. 55). The specific features that Copland's et al. students appreciated included the ease of navigation, along with the metrical, lexical, and grammatical aids (Copland et al. par. 34). One difficulty Copland et al. did find during students' use was the inability to cite specific information found therein. This issue is emphasized in the third point of the MLA-CSE scholarly standards, which is concerned with the ability to reference the information despite interface updates. Copland et al. credits this to EB's choice of JavaScript instead of traceable URLs (Copland et al. par. 33). 
Many commands may be done on the site, but detailed steps must be given for the information to be recreated.

Below (see figure 5) is a screen shot of the detailed information for cyning. There is no direct way to come to this screen as the URL remains http://ebeowulf.uky.edu/ebeo4.0/CD/main.html for the entire site. Instead, students and professors need to be specific in describing the desired screen. In the instance represented in figure 5, the transcript is on the left and the image is on the right, the critical edition, definition, grammar, translation, and meter option are all displayed, with the glossary and meter statistics popups open. All these settings are in place for the word cyning as it appears in line 1308. Given the precision needed to direct users to specific information, a simple URL may prove helpful.

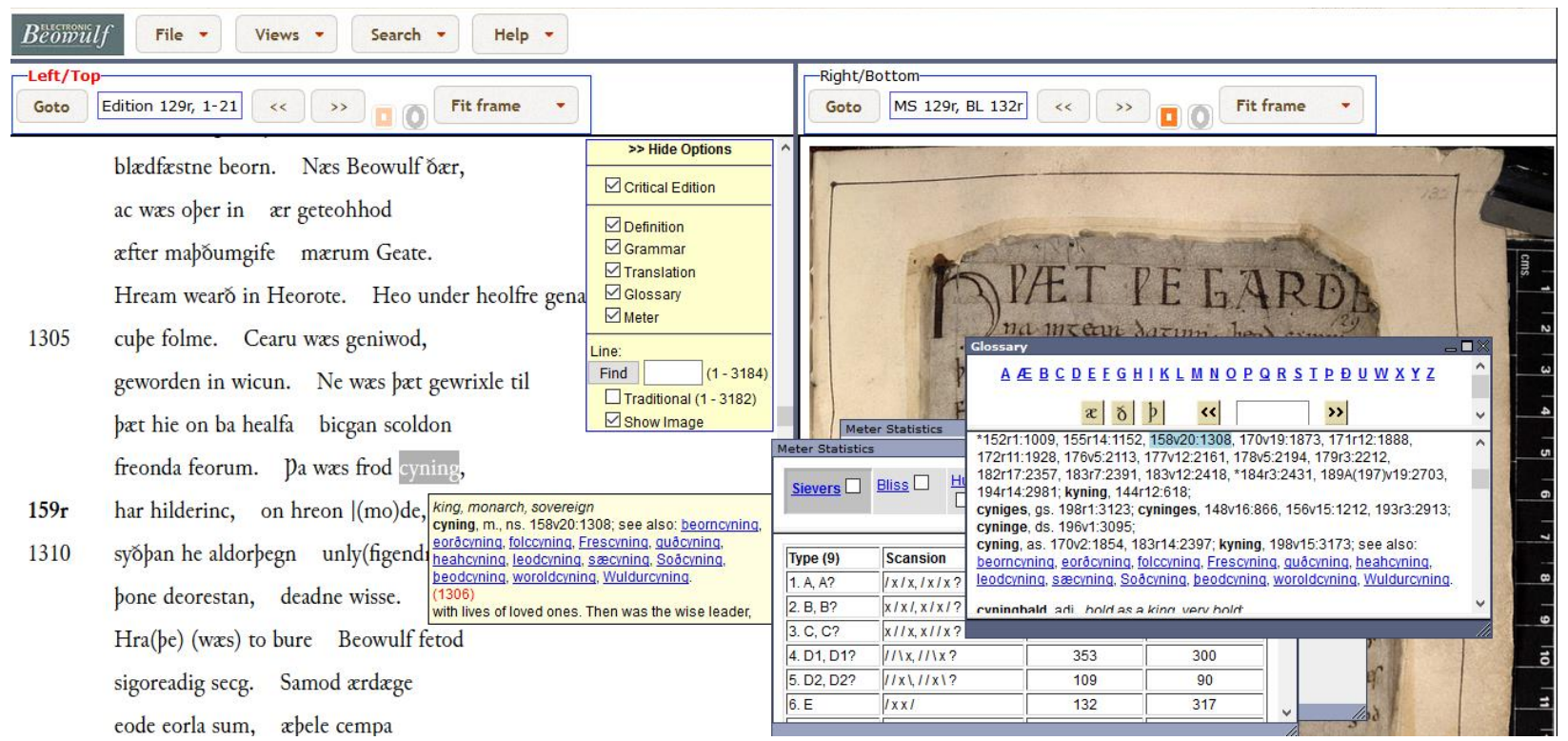

Figure 5. Sample screenshot of multiple tools open on EB 


\section{Analysis of Piers Plowman Electronic Archive}

The Piers Plowman Electronic Archive (PPEA) was first articulated as a planned idea in April 1994 by Hoyt Duggan. The plan was to create "an efficient structure for a complex archive that will eventually consist of hypertextually linked documentary editions of every manuscript; edited texts of hyparchetypes and archetypes; critical texts of versions A, B, and C; facsimiles of all witnesses; and an apparatus criticus for each text to include codicological, paleographic, linguistic, lexical, and textual annotations" (Duggan and Lyman par. 5). To form this idea, Duggan worked with John Price-Wilkin, Thornton Staples, and John Unsworth prior to the announcement.

PPEA was released on CD-ROM in 2000 and six more volumes followed until 2011. Kenna Olsen reviewed the latest volumes, six (2008) and seven (2011), in 2012, and stated, it "should be read by scholars and students of Middle English literature, manuscripts, and textual history, as they illustrate the sort of insight that can be garnered by such diligent work" (Olsen par. 32). She questioned the longevity of the CD-ROM medium, and in 2014 the work was transferred from CD-ROM to the web. Comparatively, in 2013 EB chose to publish on DVD and went online in 2015 .

Though Olsen was referring to the CD-ROM, the website maintains the same function and purpose to be used by scholars and students: "The Archive enables instructors, students, and researchers to explore late medieval literary and manuscript culture through the many variations of Piers Plowman. The long-term goal of the project is the creation of a complete archive of the medieval and early modern textual tradition of Langland's poem" (Duggan et al.). As the second line implies, PPEA is still being added to; eight manuscripts are currently in progress (as of the spring of 2018). 
The archive describes four activity suggestions for high school and college classrooms; however, the editions themselves are designed to be presented as supplemental material in high school and underclassmen college courses. The editions meticulously detail the editorial features without explaining basic knowledge of Middle English script (see figure 6). This may hinder the accessibility for younger students but including this information may be distracting to the other intended audiences, instructors and researchers, of the site. Graduate students and upperclassmen undergraduate students will benefit and appreciate the features presented in this archive, especially if they are focusing on editorial, linguistics, or paleography theory.

In comparison, PPEA checks many more boxes on the MLA Statement than EB. PPEA has clear transcriptional and technological protocols, which produces accuracy and consistency across all transcribed manuscripts (addressing point five). There is an introduction to each manuscript that highlights differences between that manuscript and other manuscripts: poetic

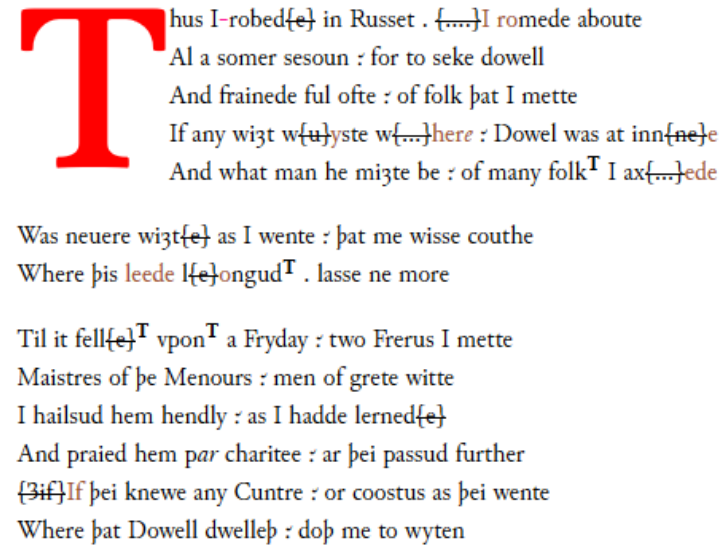

Figure 6. Sample rendering of the Middle English script as found on the PPEA 
notes such as alliteration patterns and meter, the specific procedures of the edition, and an explanation of other critical work done with the same manuscript. As a digital text, it uses TEI and has updated from CD-ROMs to the widely accessible web. The only element of a scholarly edition laid out by the MLA-CSE that seems to be neglected is the history of the archive's creation and evolution throughout the many years. Though part of the history can be found spread out over conference notes, publisher websites, and journals. The PPEA answers to the standards laid out by the MLA-CSE, both as a scholarly and digital edition.

\section{Commercial Digital Resources}

Now that I have explored two medieval digital scholarly editions, I would like to consider non-scholarly digital resources that are popular among students for the sake of understanding the student. By commercial digital resources I mean websites that offer supplemental information to students to assist them in understanding a work; for example: SparkNotes, Shmoop, ENotes, GradeSaver, and CliffsNotes. Often, as with these examples, commercial digital resources offer summaries and study guides with no full text (No Fear Translations, published by SparkNotes, is an exception and includes facing page translations such as The Canterbury Tales, Beowulf, and those by Shakespeare ${ }^{3}$ ). Wikipedia is another site that offers information on literature among other things. However, its pages are not standardized, which makes it difficult to study the potential uses and appeal to students.

\footnotetext{
${ }^{3}$ A full text is provided; however, it is problematic because no textual notes are given on the "original" transcription giving question as to how "original" it is. This is especially obvious with Beowulf as the "original" poem is written in modern English.
} 
The MLA-CSE defines editions as a place to "encounter some text or document and through which we can study it” (MLA 3). This “encounter” is slightly ambiguous as a remediation of the text, even if it is a limited perspective and standpoint (such as a summary), is still a point of connection between reader and text. Thus, commercial digital resources could be seen as editions, though not scholarly. However, I believe that the MLA-CSE is assuming that the full text is being encountered in an edition. Because viewers are not encountering the full text on these websites, I have chosen to call the websites resources as they offer supplemental information to aid the viewer. Even though commercial digital resources are not scholarly editions (which is my primary concern), I would like to take a moment and consider what they offer, because they are avenues that students use to understand and analyze texts.

Quantcast is a technology company specializing in marketing that built Q, an artificial intelligence measuring platform that analyzes the behaviors of website viewers. They provide a coding tag that can be applied to any website, and this code reports findings back to Q, which organizes the data allowing Quantcast customers to see trends in viewer behaviors, demographics, and interests. The purpose of providing this information is to inform companies of their viewers and adjust advertising and marketing accordingly. I have used this site to provide information on commercial digital resources. However, Quantcast does not break down each webpage or function of a given website, but I will at least be able to compare one site to another in general terms. Below, table 1, shows the rankings of five commercial resources based on Quantcast's data. Rank is determined by the number of people in the United States who visit the site each month. Quantcast continually updates the rank by looking at the last thirty days. Also listed in the table below are the monthly views. Shmoop, ENotes, and GradeSaver use Q and track the unique devices used each month. SparkNotes and CliffsNotes, on the other hand, do not 
use Q; even so Quantcast has estimated their views and given them a rank. The traffic of these two sites is estimated on unique individuals instead of data on unique devices. Quantcast did not have any data on EB or PPEA. This could be because neither edition use the Q tag, or they have chosen to hide their information, but most likely are too small in viewership for Quantcast to track and estimate. Quantcast does not seem limited to commercial sites only, because they do offer profiles for non-profit websites (such as Wikipedia and College Board) and academic institutions (such as UniversityofCalifornia.edu) even if these do not use the Q tag.

Shmoop and ENotes are primarily for use in high school classrooms. One probable reason for their high rank is that these commercial resources are designed to address the needs of teachers. Though individuals can subscribe to materials, there are lesson packages for teachers (with quizzes, study material for students, lesson plans, etc.). A common set up for these packages is to allow the instructor, along with a set number of students, access to the site. As

Table 1

Quantcast Ranks for Digital Commercial Resources as of 9 Feb. 2018

\begin{tabular}{|l|l|l|}
\hline Website & Rank & Traffic \\
\hline Shmoop & 233 & $8.4 \mathrm{~m}$ US unique devices monthly \\
\hline ENotes & 284 & $6.5 \mathrm{~m}$ US unique devices monthly \\
\hline GradeSaver & 580 & $3.4 \mathrm{~m}$ US unique devices monthly \\
\hline SparkNotes & 861 & $2.0 \mathrm{~m}$ US people reached monthly* \\
\hline CliffsNotes & 2147 & $.874 \mathrm{~m}$ US people reached monthly* \\
\hline
\end{tabular}

*SparkNotes and CliffsNotes do not have the Q tag and so Quantcast does not have information on devices using these resources, thus these are estimated numbers. 
seen in table 1, Shmoop has the highest rank of visitors. In contrast, GradeSaver, SparkNotes, and CliffsNotes are all optimized for the student instead of instructor and are applicable to high school as well as undergraduate students. Of these resources I will further investigate SparkNotes and CliffsNotes.

This Quantcast information is helpful in determining which sites are popular at a given time and how they compare to sites that offer similar services. However, this information does not even scratch the surface of viewer use. The information above gives a context to the resources, and the next step in understanding viewer use would be to analyze and compare the various learning tools and features offered. Little study has been done as to how students use commercial digital resources to comprehend and study literature. Thus, I contacted CliffsNotes and SparkNotes (in February 2018) about any data they might have regarding user trends. CliffsNotes was not willing to share data with me and SparkNotes did not reply to my email. The primary places that do discuss uses of commercial resources have either been the websites themselves, with a prescriptive use and purpose, or news articles and forums debating student use from the educator and student perspective. Blogs are another place where individuals discuss their use of these sites.

I provide a brief description of SparkNotes's and CliffsNotes's purpose and intended use according of their websites below. SparkNotes, launched in 1999, has been owned by Barnes and Noble since March 2001 (“A Brief History of SparkNotes”). SparkNotes's intended use is as supplemental material, "We think that SparkNotes are an excellent way to supplement your understanding of great works of literature, which can often be extremely confusing," and should be read alongside and not instead of these works ("Help"). 
CliffsNotes started as a print medium in 1958 by Clifton Keith Hillegrass (1918-2001). Hillegrass sold it in 1998 to Hungry Minds, which also owned the For Dummies series (at the time the International Data Group owned 76\% of Hungry Minds) (Fargen). Both For Dummies and CliffsNotes were sold by Hungry Minds to Wiley in 2001 ("Wiley to Acquire Hungry Minds"). Wiley held onto For Dummies but sold CliffsNotes to its current owner, Houghton Mifflin Harcourt in 2012 (Furchgott). It was under Wiley's care that CliffsNotes went online in 2004 (Reid). CliffsNotes's intended use is the same as SparkNotes, to be read alongside assigned reading. The material is designed not to be the end of the student's critical thinking or intellectual process, but to be the beginning, and not a poor beginning but a way to launch established ideas to new and unique thoughts ("About CliffsNotes").

Both sites offer guides for multiple school subjects, but I will focus only on those related to literature. Though the intended use of SparkNotes and CliffsNotes is to be supplemental reading, it is unclear to what extent students use these sites as a replacement to the primary text. Above are the prescribed uses of such sites, but now I would like to consider the discussion of use as seen in newspapers and online forums. The nature of the data is based on perceived use and not empirical study, because the data is primarily students' or instructors' commentaries on how the website is used. I have not included any comments on the prescriptive use in my research below as I am more interested in how these sites are actually used. Also, because of the ever updating and changing interfaces I have chosen to look at posts and articles that discuss SparkNotes and CliffsNotes only in the last ten years. 
I observed twelve commentaries on the use of SparkNotes and CliffsNotes. ${ }^{4}$ This discussion focuses on the free online publications of these two study guides, but they both offer print copies of the resources for a small fee. ${ }^{5}$ Seven of the commentaries surveyed are news articles, including high school and college newspapers, one is a blog by a high school teacher who uses these resources in the classroom, and the remaining four are forum posts. These commentaries are written by one New York Times reporter, three teachers, and eight students (a mix of college and high school). Granted, especially in the forums but also the news articles, students and instructors are offering their opinions simultaneously within these pieces. In these instances, I classified the document based on the author's and original poster's status. The main aspects of information I gathered are the pros and cons of the study guides mentioned by users and the website tools that are helpful (such as quizzes, summaries, glossaries, and quotes).

The commentaries describe how the study guides assist in comprehension of the reading, with two of them specifically describing using the guide to compare and clarify the students' ideas. Though comprehension is the primary assistance provided, only seven explicitly mention the summaries. With so many describing comprehension and only about half pointing out the summaries, it becomes unclear how much the summaries are playing a role in the comprehension versus the other tools offered. Being quick to read is the next popular reason to turn to these guides, with being a free resource after that. The primary concerns for using the study guides are

\footnotetext{
${ }^{4}$ The data and citations for the commentaries can be found in the appendix B.

${ }^{5}$ Barnes and Noble sells SparkNotes printed literature guides for \$5.95 and Houghton Mifflin Harcourt sells CliffsNotes printed literature notes for \$5.99 as of October 2018.
} 
the possibility of plagiarism by students of the websites' content, the limiting of critical thought, and the lack of information provided.

My purpose in analyzing these commentaries is to determine the benefits and drawbacks of such resources and the tools used by students. The summaries, both of the whole text and for each chapter, are the most valued feature. SparkNotes and CliffsNotes both include an analysis at the end of each summary, and the analyses are mentioned by two commentaries. No Fear Translation, quizzes, information on themes and symbols are also mentioned in the commentaries. But more tools and features are offered by the guides. Essay prompts and discussion questions are also provided but are not mentioned within this survey. Character lists and descriptions are offered as well, with analyses of main characters. It is difficult to determine whether these other tools offered by the sites are useful to students since they are not mentioned. SparkNotes and CliffsNotes both provide the aforementioned tools but also offer a couple unique features. SparkNotes contains important quotes with an explanation of them and the No Fear Translations (which two commentaries mentioned as useful). In contrast, CliffsNotes provides a brief historical context of the text and some include a description of the genre of the text (for example, the romance genre was described on the "Sir Gawain and the Green Knight" page). CliffsNotes also has character maps to visually represent the relationships between characters (see figure 7 for the character map of Beowulf) and provides a glossary, (which one commentary appreciated). 


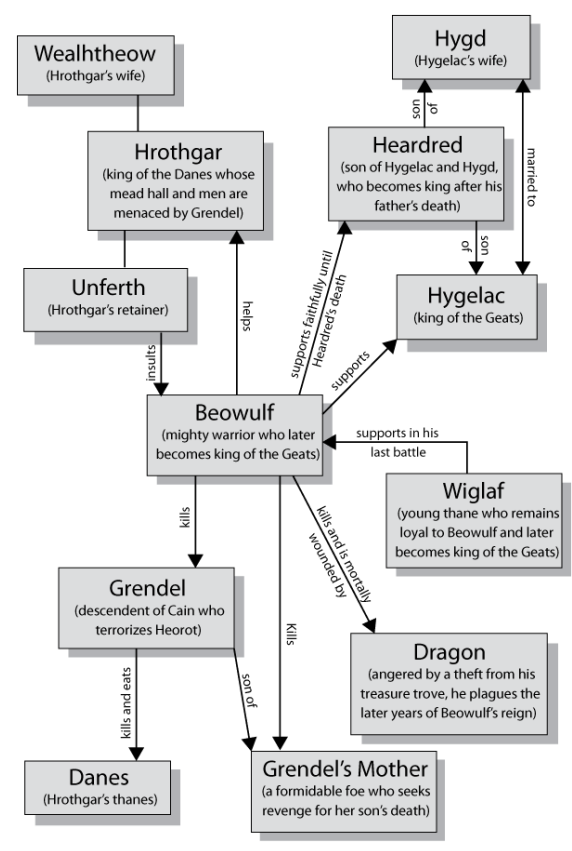

Figure 7. A character map for Beowulf created by CliffsNotes

The features I have mentioned above are concerned with the text, however other aspects of the websites that have nothing to do with the text itself may be drawing students in. For instance, SparkNotes has banners inviting the student to take study breaks (see figure 8). In contrast, other aspects, such as ads, may be pushing viewers away as ads must be navigated around and mentally filtered out to avoid distraction. 


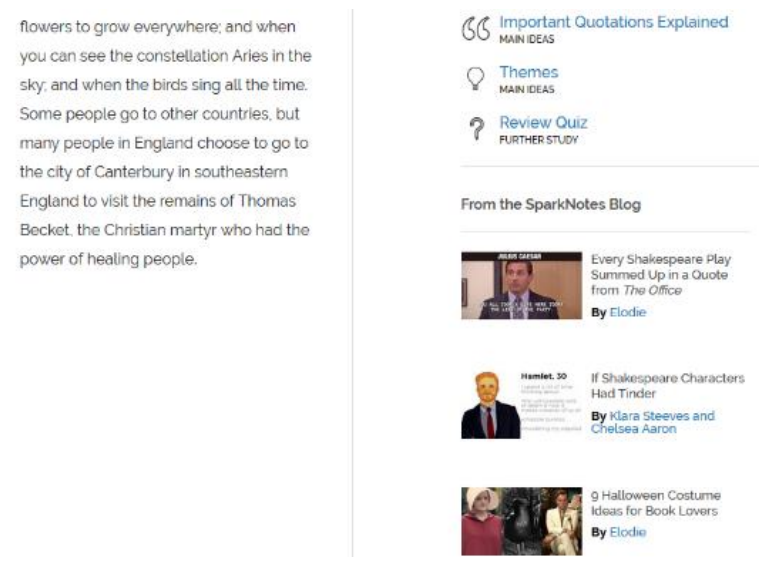

Figure 8. Canterbury Tales with a side banner for the SparkNotes blog (screen shot taken 27 Oct. 2018)

It is assumed study guides like these are being consulted, whether in lieu or in addition to the text, because they are a quick and easy read. However, one reason mentioned in Diana Kline's local newspaper article is that "kids aren't really confident in their analysis and their understanding" and thus look to study guides to obtain ideas. This was substantiated by two other commentaries that used study guides to confirm or clarify students' thoughts. This brings up an important consideration for commercial digital resources to encourage critical thinking and build confidence in students' ideas. However, just as this purpose might strengthen students it may also be the means of their demise. Estrellas's post to the forum College Confidential brings to light that students may feel discouraged if they do not see the nuances of the text that the study guide mentions: "I look at all the symbols, themes, and hidden messages the SN [SparkNotes] writers have found, and I put myself down for not finding them as well." This is a very delicate balance between encouraging students with interpretations but not limiting them to those interpretations. 
Commentaries and the guides themselves describe how sites should be used alongside the full text, as well as a place to gain understanding of the text so that the student can move forward in the research process. But, on the other side of the spectrum there is the fear that these guides are the beginning and end of the research process and no further investigation is pursued. Obviously, more research can and should be done to fully understand viewers' use of such guides and how it is used in their research process.

\section{Conclusion}

This chapter provides an analysis of digital texts and is the basis for my model as shown in chapter four. I have used the information gathered and studied here to understand the scholarly standards, as provided by the MLA Statement, and features and tools that may ease student use. My model of a scholarly digital edition primarily aids students who are working with the Old French language or the lai Le Fresne, and it may be limited in addressing the needs and inquiries of scholars. I have used the space in this chapter to inquire into the requirements and features of digital texts to better understand what could or should be included in a digital edition.

Both EB and PPEA are excellent models in digitizing medieval texts and manuscripts at a scholarly level. EB offers a library of high-quality images giving students and scholars access to the original manuscript and encouraging the textual scholarship of Beowulf. EB also provides a model for displaying linguistic information (for example, index, glossary, and meter). PPEA provides its TEI coding, which assisted me as I created my model, and lays out standards and steps to be used across all the digital manuscripts in the PPEA project.

To understand how a student might benefit from a digital edition, I went to SparkNotes and CliffsNotes because students are their primary audience. In my survey, I discovered that 
students value context in the form of a summary that may give them confidence in their conclusions. Speed is another value of students, and though scholarship and learning are not quick processes, providing speed in other ways, such as website navigation and design is appreciated. I will create my model based on the features of digital scholarly editions and commercial digital resources while keeping in mind the possible pitfalls.

The next chapter studies the lai Le Fresne by Marie de France. I will highlight translational choices and the implications of those on readers' interpretation. I would like my model to make transparent to readers the translational choices an editor must consider. These first chapters work together in providing a digital and textual context that is needed to create my own model for a digital edition of Le Fresne. 


\section{CHAPTER III: TRANSLATORS OF LE FRESNE}

\section{Textual History}

The author of Le Fresne is generally accepted to be Marie de France; however, there is no clear evidence linking the figure of Marie to any single and unambiguously identifiable historical figure during the mid-twelfth century. The name "Marie de France" is derived from the epilogue to a collection of fables found in MS Harley 978 and was first coined by Claude Fauchet (1581) (Gilbert xi; Mickel 13). "Marie ai num, si sui de France” (My name is Marie, and I am from France) (Kibler 1); this declaration of name and place shows that Marie's birthplace is France but that she is also composing the fables outside of France (Mickel 16). Within the same manuscript are lais, also claiming to be written by someone named Marie: “Good seigneurs, listen to Marie" (Guigemar 3, translated by Gilbert). Thomas Tyrwhitt (1775) was the first to claim that The Lais and The Fables were written by the same person (Gallagher xi). Shortly after Tyrwhitt's claim, Legrand d'Aussy (1781) identified Tyrwhitt's Marie as the translator of Espurgatoire Saint Patriz. The writer of Espurgatoire Saint Patriz names herself as Marie and describes her goal to put the book into the vernacular language so that it may be widely understood (Mickel 13). By using evidence found in all three works, The Fables, The Lais, and Espurgatoire Saint Patriz, Emanuel Mickel (Marie de France, 1974) has posited the compositions to date from 1155 at the earliest, to about 1208, with the lais specifically dating to 1155 through 1200 .

1155 is cited as the beginning of Marie's compositions because the poet Wace finished his work, Roman de Brut, in that year. Mickel considers the geographical references made by Marie and traces them back to Wace: "It should be pointed out that the geographical references in the lais, when not borrowed from Wace, are vague and give little evidence of personal 
acquaintance" (17). This shows Marie's reliance on Wace's work, and also suggests Marie's lack of familiarity with the French countryside, giving weight to her identity as a Frenchwoman living in England. Mickel supports this further by pointing out "that her knowledge of Southern England and South Wales seems, in general, more precise than her knowledge of the continent" (Mickel 17).

Mickel cites 1200 as the end of the period during which the lais were written, though a span from 1155 to 1170 is more popular among scholars, including Sif Rikhardsdottir ("The Imperial Implications of Medieval Translation," 2007, 146) and Erin Goeres ("Sounds of Silence,” 2014, 281). Paula Clifford (Marie De France Lais, 1982) gives the 1170 date based on Eleanor of Aquitaine's imprisonment in 1173. She notes that the royal couple were patrons of the arts (10). Clifford also cites Chrétien de Troyes, a contemporary, who shows signs of having been influenced by Marie's lais in his piece Erec et Enide (1170). Chrétien's works date from 1160 to 1190; however, though Chrétien was likely a contemporary, Mickel indicates there is no evidence of Chrétien's influence on Marie. Mickel's further date of 1200 is to mark the last possible date that the lais were created. This cap is provided by Guillaume de Dole's (1200) reference to Lanval and that the Archbishopric of Dol, mentioned in Le Fresne, was dissolved in 1199 by Innocent III (Mickel 19).

Based on the date and location, the king to whom The Lais are dedicated, "To honor you, most noble King" (49), is likely Henry II Plantagenet (reigned 1154-1189). ${ }^{6}$ Mickel posits that the latest date of the lais is 1200; however, if the poems are dedicated to Henry II, it would be

\footnotetext{
${ }^{6}$ King Philip Augustus of France and Henry the Young King (the son of King Henry II) have both been postulated as the dedicatee.
} 
unlikely that they were written after his death in 1189. Also, Marie is looking for a response from her king:

I in my heart thought this I'd do,

Fair Sire: present this work to you.

If it should please you to receive

My gift, for all the days I live

I shall be joyful; you shall give great happiness. (Prologue 49-54, translated by Gilbert) Marie is reliant on her dedicatee to accept and receive the lais and thus to actively give her happiness. If it were written posthumously, it would be assumed the dedicator lived a joyless and unhappy life, an irony that seems to be lacking presence in the rest of the dedication.

The dedication of the lais to a king does not prove Marie's ties to the court, but understanding her education will show that she likely was from an aristocratic family. As seen in the works attributed to her, we can gather that she knew French, English, and Latin. Also, The Fables were translated from English into French, according to the author, and Espurgatoire Saint Patriz was translated from Latin into English (Mickel 16). It appears the author is well read based on the literary references within the collections: Guigemar includes the burning of a book by Ovid; Bisclavret has an allusion to Metamorphoses and a biblical allusion to a bed similar to King Solomon's bed; Lanval references a mythical Assyrian Queen; The Fables show elements of the Aesopic tradition; and the Prologue to the lais names Priscian, a sixth century Latin grammarian.

The author also follows contemporary literary concepts, demonstrating her knowledge of contemporary works. I have mentioned the impact of Wace's Brut above. Another example includes the mention of mesure in the lai Les Deus Amanz Mesure is the concept of being in the 
right place, at the right time, and responding to the situation with the right degree of action (Gilbert 87). Dorothy Gilbert, Marie de France Poetry (2015), indicates that this virtue and its opposite, demesure, were popular motifs of the twelfth century; Chanson de Roland (c. 1100) also includes this motif (87). Mickel cites the influence of Geoffrey of Monmouth's Historia regum Britanniae (1135) and Gaimar's Estoire des Engleis and Eneas (22).

Marie's literary understanding and language knowledge point toward an aristocratic birth. Scholars have tried to pinpoint a specific Marie and several theories have arisen, though none are fully conclusive. Gilbert lists the Marie, Abbess of Shaftesbury ${ }^{7}$ (Henry II's illegitimate halfsister); Marie, Abbess of Reading; Marie, Countess of Boulogne; and Marie de Meulan (the daughter of a Burgundy nobleman) (xi). Edward Gallagher, The Lays of Marie de France (2010), adds Marie de Compiègne, who was a likely candidate while the authorship was dated to the thirteenth century, and Marie de Champagne (daughter of Eleanor of Aquitaine and Louis VII). Robert Cook and Mattias Tveitane, Strengleikar (1979), as well as June Hall McCash, "Sidney Painter" (2003), note the abbess of Shaftesbury as the most plausible. John Charles Fox was the first to suggest the abbesses of Shaftesbury in 1910, once the manuscript's dating was changed from the thirteenth to twelfth century. Though McCash also notes the importance of Marie de

\footnotetext{
${ }^{7}$ Marie, Abbess of Shaftsbury, was the daughter of Geoffrey Plantagenet and held the position from 1181 to 1216. John Charles Fox posits that King Alfred wrote the English translations of The Fables and was also the founder of the abbey. He also tracked a version (though not Marie's) of Espurgatoire Saint Patriz to have belonged at the abbey as well. Thus, it is quite possible that this Marie had good source texts to consult.
} 
Meulan: "Probably the most compelling and popular rival to the Abbess of Shaftesbury is Marie de Meulan, first proposed by Holmes in 1932" (194).

A final theory of Marie's identity first put forth by Richard Baum, Recherches sur les Auvres Attributées à Marie de France (1968), is that she is a collective author rather than a single individual. Cook and Tveitane ${ }^{8}$ give evidence for this by pointing out that Marie names herself once in the collection of lais, that appears in the beginning lines of Guigemar. This, coupled with the argument that the Prologue is only for Guigemar and not the entire collection, supports the possibility that The Lais were written by multiple people. Having multiple authors however does not seem compelling because it is arguing from the absence of information. A second and stronger reason put forth for the multiple authorship theory is described by Rudolph Keyser and Carl Unger, Strengleikar Eða Lioðabok, (1850):

De Udtryk, hvori Marie her nævnes, forekomme os imidlertid mere at ligne et Citat hentet af Digterindens Arbeider, en Paaberaabelse af hendes Autoritet, end en ligefrem Yttring af hende selv som Digtets Forfatterske, og hvis denne vor Anskuelse skulde være rigtig, saa maa det anforte Sted snarere tale mod end for hendes Forfatterskab med Hensyn til Samlingen af Lais. (Unger ix)

(The expressions used about Marie here seem to us more like a quotation from a work by the poetess, an invocation of her authority, than a statement made by herself as the authoress of the poem, and if this view of ours should be correct, this particular quotation

\footnotetext{
${ }^{8}$ Richard Baum and Povl Skarup have also written on this subject. Both their works are written in French with no English translation as of May 2018.
} 
would speak rather against than for her authorship as regards the collection of lais.) (translated by Cook and Tveitane)

This second argument claims that the authorial mention adds an authoritative effect rather than accurate authorship. This theory highlights that it is more important who might say it or in what style something is said, than who actually says it. As a stylistic move, it is quite possible that the real author(s) were not named Marie, and instead ascribed to her tradition.

\section{Breton Lais}

Marie's poetry follows the tradition of Breton ${ }^{9}$ lais, which were popular during the period between 1150 and 1450 (Laskaya and Salisbury 1). They typically contain romantic conventions, including idealized, aristocratic characters, elements of chivalry, and courtly love. Although the lais are usually introduced as part of the Breton tradition and they follow a few general conventions, it can be difficult to distinguish between Breton lais and other short romances. Similarly to how the name Marie might be used to sign post a specific literary style rather than a specific author, so might the classification of Breton lai say more about the literary style than the origins of the poem.

Traditionally Breton lais were "sung by ancient Bretons to the accompaniment of the harp;" a genre of oral tradition (Laskaya and Salisbury 1). Because these lais stem from oral tradition, Leo Carruthers, "What Makes Breton Lays 'Breton'” (2018), claims that Marie's work is the first written occurrence of this genre (par. 2). The setting is often located in a Celtic area,

\footnotetext{
${ }^{9}$ Breton is a Celtic language and culture, referring to pre-Anglo-Saxon settlements in both Southern England and Northern France.
} 
including Northern France where Le Fresne takes place. ${ }^{10}$ The poem begins with two knights and their wives living in Brittany, and later Bruron, ${ }^{11}$ from Dol (located in upper Brittany), is introduced (lines 3). The Celtic heritage also influences the folklore and mystical elements of the plot, such as in Bisclavret and his werewolf transformation (though werewolves are also present in other traditions, such as the Germanic). All of Marie's lais, including Le Fresne, are written as octosyllabic couplets, giving a distinctive form to them. I will keep the above description of Breton lais short to avoid the pitfall described below by Anne Laskaya and Eve Salisbury, The Middle English Breton Lays (1995):

The poems often fall into some pattern based on story type or linguistic model depending on the particular critic's criteria for evaluation. Yet the attempt to impose a single formulaic pattern on these texts in order to determine a genre has been thwarted by their resistance to conform to any single cohesive system. (2-3)

Though Laskaya and Salisbury warn against formulaic patterns for Breton Lais, a few exist that are worth noting in conjunction with Le Fresne. Derek Brewer, Symbolic Stories (1980), formularizes traditional stories (for instance, myth, folktale, medieval romances, and great novels) as a "family drama." This concept includes a specific narrative structure where "the protagonist of the story is a representative of the emerging human adult breaking out from the environment of the home and parents" (Brewer 9). The story circulates around the protagonist,

${ }^{10}$ Carruthers argues that one source of confusion in identifying Breton lais involves the place and people referred to as "Bretons;" the misconceptions are attributed to the close association of Britain and Brittany.

${ }^{11}$ Also written as Gurun. 
father, and mother. A fourth character is also present though less active; "the peer" as Brewer calls it, is a character who is usually the opposite sex and the same age and attitude as the protagonist. The plot follows as such:

To put the matter with crude brevity: what the male protagonist has to do is kill his father, dodge his mother, and win his girl. The female protagonist has to dodge her father, and if not kill at any rate pretty severely neutralize her mother, and make it possible for her man to get her. ... Usually reconciliation with parent-figures is also achieved. (Brewer 9) Thomas A. Shippey, "Breton Lais and Modern Fantasies" (1988), draws on Derek Brewer's work on the "family drama" and relates it to the structure of Breton lais and specifically Le Fresne. Le Fresne's mother rejects her as an infant while her father does not even know of her existence, thus the "dodging" and "neutralizing" is complete. She then meets a young man, Bruron, while living with her foster family. After living with Bruron for some time, Le Fresne has not conceived children and so his men seek to find him a fertile wife. Le Fresne graciously steps aside to allow this new woman (incidentally her sister) into her former place. Le Fresne places a fine and unique cloth, given to her by her mother at her birth, on the wedding bed. Le Fresne's mother recognizes the cloth and confesses her fault, thus reconciling Le Fresne to her family and allowing her to marry the young man with a dowry.

While the "family drama" concept provides a structure for the central characters, Laskaya and Salisbury's focus on the plot arc of the main character's separation, reunion, and "a corresponding resolution of the hero or heroine's identity, purpose, and place in the world" provides more clearly a means to distinguish the structure of the lai from other family drama texts (2). The family drama is the means by which Le Fresne discovers her identity and creates for herself a place in the world. Le Fresne's growth and tension is the center of the lais and the 
drama provides a structure for this tension to be explored. If Le Fresne's identity was understood, the family drama could possibly take place as outlined above, but Le Fresne's character would have to develop in new ways that would change the essence of the story. The family drama might always exist in a text, but the development of the hero or heroine defines the text, making it distinct from other family drama texts.

After understanding the content and plot of the lais, it is important to also consider their mechanics and structure as these provide a physical context to the narratives. The mechanics of specifically Marie's twelve lais (and the Prologue) include octosyllabic couplets (utilizing end, or tail, rhyme) ranging in length from 118 lines (Chevrefoil) to 1,184 lines (Eliduc). There is also a distinct opening and closing structure to the poems. For each lai, "Marie provides a miniprologue and epilogue in which she both speaks of her source and describes what she has written, using terms like 'lay,' 'adventure,' 'tale,' and 'story,' but with less than absolute consistency" (Gallagher xvi). Gallagher lists eight lais that do this: Guigemar, Equitan, Lanval, Les Deus Amanz, Laüstic, Milun, Le Chaitivel, and Eliduc. However, I would not limit Gallagher's classification to these eight alone but would include the final four as well. Le Fresne, Bisclavret, Yönec, and Chevrefoil also begin with a mini-prologue, end with a mini-epilogue, and contain words like "lay," "adventure," "tale," and "story." Perhaps Gallagher finds the four lais lacking in source information. Though the citation for each lai is vague. Guigemar, Equitan, Les Deus Amanz, Laüstic, and Eliduc cite the Breton poets. Milun references the "ancients," which could possibly be the Bretons: "the ancients made the lai above" (531). Bisclavret and Lanval are remarked as Breton names, inferring their heritage.

The story of another lai,

Just as it happened, I will say. 
It's of a young, most noble man;

He was called Lanval in Breton. (Lanval 1-4, translated by Gilbert)

In crafting lays, I won't forget

- I mustn't - that of Bisclavret;

Bisclavret: so named in Breton;

But Garwaf in the Norman tongue. (Bisclavret 1-4, translated by Gilbert)

Le Chaitivel cites the town in which the story takes place: "I'll tell the story of the lai / and the town I'll identify / where the tale was conceived and born" (Gilbert 2-4). Le Fresne, Yönec, and Chevrefoil do not give any indication of the source except for inferring that Marie is not the originator as she states she is recounting the tales. Le Fresne begins: "Du lay du Fresne vos dirai / Selonc le conte que je sai" (I will tell you of the lai Le Fresne / According to the tale which I know) (1-2). ${ }^{12}$ As discussed above, the label of "Breton lais" could describe the style of the poems more accurately than describing the source material of the poem. Thus, classifying the lais based on source material may prove futile.

It is useful to have a notion of the distinctive genre of Breton lais, because as the syntax and plot are translated into a target language, so must the form be translated as "style encodes the source writer's attitude towards the content" (Jones 173). Francis Jones lays out three main approaches for translating the form of a poem in The Oxford Handbook of Translation Studies (2011). First, mimetic is the replicating of the original form; second, analogical uses a target

\footnotetext{
${ }^{12}$ All lines quoted from Le Fresne are taken from the Kibler transcription and are translated by me.
} 
form that is similar in cultural meaning to the source form; and finally organic, which gives the translator freedom to choose a form he/she believes best suits the target text (173). It is key to understand the source genre structure so as to effectively translate it into the target genre.

Specifically taking into account the octosyllabic couplets with end rhyme, length, and opening and closing structure, a translator may then consider the ideal structure for the target text. Gilbert has translated the text with a cross between the mimetic and analogical methods. She maintains the plot structure, translating line by line, but exchanges the octosyllablic couplets for iambic tetrameter to allow for the natural rhythm of English stresses. Also, instead of end rhymes, she opts for slant or half rhymes (xiv). Gallagher's translation is purely organic in his prose translation as he sets aside the poetic structure and rhyme scheme. He maintains the parataxis, though he updates the verb tenses (which oscillate between past and present tense) to strictly past tense to maintain modern conventions (xxv). I have translated in a mimetic and organic structure; I disregard the rhyming and syllabic structure to focus on a word for word translation with the goal of maintaining the semantics of the source text.

\section{Artifacts}

I would like to consider interpretation as part of the translational process. To do this I will start by studying how the objects surrounding Le Fresne, the character, are interpreted by the other characters and how that interpretation translates to the others' actions. Then I would like to juxtapose this with how translational choices become a collaboration with the text. Studying translation in these terms makes explicit the decisions which are often assumed or concealed. I believe the concept of translation is important to understanding how texts are moved in the story world and in the real world. By studying the translation of Le Fresne, we understand her agency. 
Le Fresne is a tale particularly rich in moments of translation. The characters work to translate Le Fresne as she moves from one place to another. This parallels to the lai itself, which was translated into three more languages in its early history and is translated and adapted for today's readers. As illustrated by Le Fresne, the translation process enables the translator to express his/her own unique take on a text by making editorial decisions that shape the reader's understanding of that text.

There are four medieval manuscripts ${ }^{13}$ that include this particular lai, each in a different language. The manuscripts are dated to about a century after Marie is assumed to have composed them in the mid-twelfth century. The Anglo-Norman text is considered the authoritative collection of the lais; the Old French and Anglo-Norman manuscripts both date to the midthirteenth century; the Old Norse text dates to the late-thirteenth century; and the Middle English manuscript appears about 150 years after Marie, in the early-fourteenth century.

The translational travels of Le Fresne shape the story as it is adapted to the new culture. "The translator, far from being an invisible servant of the original text, became its authoritative voice, and the purpose of the translation was in the end not to supplement the original but to 'substitute itself for its source and efface the presence of that source"' (Longard 17). The active presence of the translator can be seen as a "translation involves the collusion or the collision of peoples and their ideas" (Longard 18). For over a century, Marie's work has colluded or collided with the French, the Norwegian court, the aristocracy of England, and then England at large.

\footnotetext{
${ }^{13}$ Further descriptions of these manuscripts are in appendix A.
} 


\section{Translating Le Fresne}

As seen above, Le Fresne historically has been translated and adapted multiple times. Not only has the text Le Fresne been translated and reinterpreted, but so, within the world of the text, has Le Fresne the character. Le Fresne is abandoned and exiled by her mother because of what she represents - a bastard child - not what she is - a twin. When sending her daughter into exile she gives Le Fresne a ring and an expensive, beautiful cloth. As Le Fresne matures and moves through the world, these two items define her, and another item is added, an ash tree. These items or objects can be used to track Le Fresne and her "identity, purpose, and place in the world" as they journey along with her (Laskaya and Salisbury 2).

There are six distinct moments when the objects are used by others to identify or give purpose to Le Fresne. The ring and cloth first appear when Le Fresne's mother chooses the artifacts to represent Le Fresne (121-134), after which the doorman and his daughter discover them and determine Le Fresne's noble birth (207-210). When Le Fresne is found in a tree by the doorman, the tree becomes another defining object, as le fresne means ash tree, and the nameless foundling becomes known by the word for the tree (228-230). With great care, Le Fresne brings the ring and cloth with her to Bruron's castle (311-314). Bruron's men do not trust the ring and cloth to prove Le Fresne's origins, but they were enough for the abbess and doorman. In contrast the men see Le Fresne's namesake as an accurate representation of her fertility (321-338). In the end, Le Fresne's mother discovers the artifacts and explains Le Fresne's birth (434-484). The selections of the poem mentioned below are taken from William Kibler's 1984 transcription of the Old French manuscript held at the Bibliothèque Nationale in France, though the translation is my own.

121) En un chief d'un molt bel chainsil In an end piece of a very beautiful linen 
cloth

Envelopent l'enfant gentil

Dedesus d'un paille roé:

Son sire li ot aporté

125) De Costentinoble ou il fu;

Onques si bon n'orent veü.

Et d'une piece d'un sien laz

Un gros anel li lie au braz.

De fin or i avoit une once;

130) El ceston ot une jargonce;

La verge entor estoit letree.

La ou la meschine ert trovee,

Bien sachent tuit veraiement

Qu'ele est nee de haute gent.
She wraps the noble child

Within a silk and gold threaded cloth with round designs:

Her husband had brought it

From Constantinople where he was;

Never such a good cloth had anyone seen.

And with a piece of her lace

A large ring ties at her arm.

It had one ounce of pure gold;

On the mounting there was a precious stone;

The band was inscribed all around.

There where the young girl would be found,

All know well truly

That she is born of exalted lineage.

These lines introduce the artifacts and explain how Le Fresne came to possess them. Le Fresne's mother is never named but is referred to as la dame (the lady) (117). La dame wraps the child in a precious piece of cloth. The reference to Constantinople in line 125, and the silk description of the cloth, paille, suggest that it is Byzantine silk. The Byzantine silks were luxurious, ornate textiles, that were just as precious as gold (Ousterhout).

The ring and gem stone may also have been from the Byzantine trade routes. Kibler notes that jargonce could be hyacinth, jacounce, or jacinth. These three names all refer to the same gem, which today classifies a golden to red-brown zircon stone (“Jacinth"). Zircon is found 
throughout the world, including Brazil, Nigeria, Tanzania, Thailand, Vietnam, and Australia ("Zircon"). Gallagher translates it as a "ruby" (22), while the Middle English translation does not mention a stone or an inscription, only "a ring of gold fin" (140). It is also curious that the inscription is never revealed, and later instances do not remark on it either. Most likely the inscription is not a personalized message, otherwise it would have been used by the doorman and abbess to identify Le Fresne. It could be the stamp of the goldsmith. This would indicate the location the ring was made and thus a possible location and nationality of the buyer. But if the ring was made in the East and passed by merchants, this inscription would provide no additional identification to Le Fresne's heritage, besides the obvious wealth that gold and a gem imply. Deborah Nelson, "The Implications of Love and Sacrifice in 'Fresne' and 'Eliduc'” (1978), indicates that this stone was "noted in the twelfth century for its power to assure its wearer safe voyage and warm reception as a guest," making it a fitting token for Le Fresne as she moves from place to place (153).

E. Jane Burns, Courtly Love Undressed (2005), discusses the transfer of goods along the European and Middle Eastern trade routes. She contrasts the goods that have the marked geographic location and culture of the East but are placed on European courtly heroines, creating a hybrid text and textile. The silk and ring are themselves translated as they move from Constantinople to Brittany. When placed on Le Fresne they signify wealth and foreignness; they “mark that purportedly western identity as utterly dependent for its visual recognition and social definition on goods bearing, paradoxically, the names of eastern cities" (Burns 183). This hybrid highlights the cultural and economic tensions, but it also exemplifies the displacements of the character, as the silk, ring, and Le Fresne are exiled from their first location and culture. 
Burns describes the term paille as generic, "denot[ing] costly silk fabric and the spectrum of luxury goods fashioned from it: tents, tapestries, wall hangings, bed curtains, and coverlets, as well as luxury garments" (187). Le Fresne's paille is not described in any particular form. It is possible it is still a raw fabric, with no particular use or identity, as it is draped over the bed, and only the general term, paille, is used (411-12). As it moves from place to place, its purpose changes. The fabric is first a gift from the knight to his wife (124) and the wife uses it as a swaddling cloth (122). Then, when the abbess tells Le Fresne of her history, Le Fresne carefully places it in a small chest as a keepsake (312). Finally, Le Fresne uses it as a bed covering (412). The purpose of the cloth is never fully defined but changes to fit the situation, and so is Le Fresne's identity changing purpose as she moves from place to place. Both Le Fresne and the cloth have yet to be made into anything with a single distinct identity.

The next instance of the cloth and ring comes as the doorman discovers the baby.

207) Entor son braz trueve l'anel;

Le paille virent riche et bel.

Bien connurent a escïent

Qu'ele ert nee de haute gent.
Around her arm she (the doorman's daughter) finds the ring;

They saw the rich cloth

They knew well with certainty.

That she was born of exalted lineage.

The purpose of the ring and cloth, which are precious, costly, and exotic artifacts, is to mark the child's noble birth; that all may know, "Qu'ele ert nee de haute gent" (That she was born of exalted lineage) (210), which is the exact purpose intended by la dame and noted when the items are first bestowed on Le Fresne in line 134. The only difference between the two lines is the imperfect use of the auxiliary "to be," ert, in line 210, and the present use, est, in line 134 . The use of est highlights the beginning and first use of these artifacts in this particular way, whereas 
the imperfect exemplifies the unknown beginning of Le Fresne's story. But both, la dame and the doorman, come to the same conclusion as to the ring and cloth's purpose. As they understand the significance of the artifacts, one more is attached to her: the tree in which she was placed.

228) Por ce qu'el fresne fu trovee, Since she in the ash tree was found,

Le Fresne li mistrent a non Le Fresne they named her

Et le Fresne l'apele l'on. One calls her the ash tree.

When the doorman tells the abbess, who employs him, of the baby in the tree, she asks to see everything, "Tout ainsi comme il fu trovez" (all entirely as it was found) (218). The abbess's specific reaction to the cloth and ring is not noted. Following viewing the evidence, the abbess names the child after the location the child is found in and adopts her as her niece and raises her at the cloister (231-33). It should be noted that the abbess sees the artifacts and then adopts the child. It could be that the abbess would have adopted Le Fresne even if she had been found wrapped in rags, but it seems unlikely that the artifacts would not influence her in some way.

Perhaps the most powerful object attributed to Le Fresne, the tree was chosen by two characters who are otherwise unrelated: the young girl who waited on la dame and the abbess. The power of this object is enacted by the abbess through naming and is continually re-evoked each time Le Fresne's name is said. The name comes up again and again each time it is written, and thus shapes Le Fresne more than the ring and cloth, although the tree as an image is only used twice to define Le Fresne (when Le Fresne is named by the abbess, and later when the men of Bruron dismiss Le Fresne as a suitable wife for their lord).

165) Quant sa priere avoit finee, Ariere soi s'est regardee, Un fresne voit, lé et branchu
When her prayer had ended, Behind herself she looked around, An ash tree sees, wide and branching 
Et molt espés et bien foillu; $\quad$ And very thick and quite leafy;

En quatre fors estoit quarrez; $\quad$ In four forks the tree was divided;

170) Por ombre estoit illec plantez. At that place it was planted for shade.

The lady-in-waiting, who places Le Fresne in the tree, does not foresee the impact this location will have on the child. She is thinking about the healthy, lush branches of the tree and the protection they would offer as it is shaped like a cradle, "En quatre fors estoit quarrez" (In four forks the tree was divided) (169). The lady is not translating Le Fresne nor finding a place that would fit her perception of Le Fresne, but she is defining the tree based on the present needs of the child. In this sense, the tree and Le Fresne translate each other by creating a context, identity, and purpose for the other.

Whereas the ring and cloth carry a similar meaning to each character, the tree is understood very differently by each character. The cloth and the ring (most likely) are foreign objects of wealth from the East, but the tree is native, literally rooted in the land. The tree does not signify economic means, and its ordinariness contrasts with the others' elaborateness. As we see above, the lady-in-waiting sees a haven and the abbess sees a name. Later Bruron's men will disapprove of Le Fresne because of her name. Only the abbess and doorman know Le Fresne's namesake, and because that symbolism is not widely understood, this object of Le Fresne is translated and interpreted differently. The barrenness of the tree is noted by the men, but not the good health and beauty, which the lady-in-waiting notices. Two different perspectives contribute to how Le Fresne, the character, is understood by other characters.

When Le Fresne is about to leave the cloister with Bruron, the abbess tells Le Fresne how she was found. The abbess then gives Le Fresne the ring and cloth to keep:

311) La meschine bien les garda; $\quad$ The young girl guarded them well; 
En un coffre les enferma.

Le coffer fist o soi porter,

$\mathrm{Nu}$ volt lessier ne oublier.
In a small chest she enclosed them.

The small chest she carried with her,

She didn't want to abandon nor forget it.

This is the first time Le Fresne learns about the objects that define her: the tree, the ring, and the cloth. Once she learns about the ring and cloth, she treasures them as she guards and carries them with her. It is difficult to deduce whether Le Fresne accepts the interpretations others have created, as her voice is not heard until the very end when she is recounting the history of the silk to her mother. Le Fresne obviously accepts the items, but it is unclear how she understands their meaning.

In the below section we have Bruron's men challenging their lord to marry, but not his mistress, Le Fresne. The importance of this context is that Le Fresne has been with Bruron longuement (for a long while) but has not conceived any children (321). They ascribe this to her namesake, the ash tree:

"Sire," font il, "ci pres de nos

340) A un preudom; per est a vos.

Une fille a, si n'a plus d'oir;

Molt poez terre o li avoir.

La Coudre a non la damoisele, En tout cest païs n'a tant bele.

345) Por le Fresne que vos perdroiz En eschange la Coudre avoirz. En la coudre a noiz et deduiz;
"Lord," they said, "here near us

Is a good man; an equal to you.

A daughter he has, and he does not have another heir;

Much land can you have with her.

The young lady's name is La Coudre,

In all this land there is no one so beautiful.

For Le Fresne that you will lose

In exchange you will have La Coudre.

In hazel trees there are nuts and pleasures; 
Le Fresne n'a onques nus fruiz. The ash tree will never have any fruit. Here the men directly identify Le Fresne by her name and the object it stands for. Fertility is not determined by a name, but the symbolism is duly noted here as the sisters are contrasted. La Coudre, meaning hazel tree, is valued because hazel trees produce the fruit of hazelnuts, and thus Bruron's men assume and appropriate this reproductive attribute onto La Coudre. The same is with Le Fresne, meaning ash tree, which does not produce fruit and thus describes her bareness. The men are simultaneously contrasting the women and the objects that identify them. The men do not name the ring or the cloth, so the reader cannot determine if the men know about them and thus understand that Le Fresne is a nobleman's daughter. However, the men do mention a defining object that La Coudre possesses and which Le Fresne does not - land. Though Le Fresne has a beautiful, expensive cloth and a gold and gemstone ring, these precious items do not warrant favor with the men (assuming they know of them), but land, which has a longer legacy than the cloth and ring, is preferred. The irony of this situation is that, when Le Fresne's identity is discovered and she is given a share of her father's inheritance, most likely including the land, the men accept her, even though Le Fresne's fertility has not changed. Le Fresne, who was once displaced, is now able to set her roots in the land that has returned to her. Though this is metaphorical, as Le Fresne stays with Bruron, it does represent the resolution of the narrative and the end of Le Fresne's journey in discovering her place in the world.

The line "En la coudre a noiz et deduiz" (In hazel trees there are nuts and pleasures) is an important translational instance which highlights the interpretational choices of translators (347). Deduiz is the plural object form for "pleasures." It can also mean: enjoyment; merry-making; sport, amusement; game, quarry; or sexual pleasure (Hindley et al. 184). In this context a double meaning is present. The analogy is that La Coudre will have children and will bring joy to 
Bruron both emotionally and sexually. This translational choice will determine the interpretational opportunities of its readers, especially if this is the only translation read. The Middle English translation does not maintain this play on words or explicitly connect fertility to the namesakes. Instead, after the knights have put forth their case and a new bride is chosen, the names are somewhat compared: “For in Romaunce Le Frain 'ash' is, / And Le Codre 'hazel,' ywis" (347-8) ${ }^{14}$ Pleasaunce is mentioned two lines later in the translation but in reference to the wedding feast with no double meaning. The Old Norse manuscript maintains a close translation and includes the double meaning: "fyrir Pui skalltu nu skifta æskionni i hæsli at askr berr alldri alldin ne huggan. en hasl berr netr ok skæmtan" (Therefore you shall now exchange the ash for the hazel, for an ash never bears fruit nor comfort, but a hazel bears nuts and delight) (par. 9, translated by Cook and Tveitane). Huggan (comfort) and skamtan (entertainment or amusement) can be inferred as sexual comfort and enjoyment. Gilbert's translation ${ }^{15}$ states, "La Codre will make tasty nuts; / Le Fresne, none; she bears no fruits" (339-40). Tasty here could refer to the sexual pleasures implied by the Old French and Old Norse translations, but the connection is not as clear. The Middle English and Gilbert translations do not draw attention to this play on words and so lose this dynamic of a hidden conversation of the men interpreting Le Fresne's sexual performance.

${ }^{14}$ I use Anne Laskaya and Eve Salisbury's transcription of the Middle English manuscript, The Middle English Breton Lays (1995).

${ }^{15}$ Gilbert's translation is based on Jean Rychner's Les Lais de Marie de France, which is based on the Harley manuscript. 
When la dame prepares for La Coudre's wedding, she discovers the artifacts that she gave to Le Fresne at birth. These two artifacts have journeyed with Le Fresne and have brought Le Fresne back to her heritage. After seeing the cloth and ring, la dame:

451) Ne doute rien, bien set et croit

Que le Fresne sa fille estoit. Oiant toz dit, nu cele mie:

"Tu es ma fille, bele amie!"
Doubts nothing, she well knows and believes

That Le Fresne was her daughter. Before all she speaks, she does not hide it at all:

"You are my daughter, miss!"

La dame uses the artifacts as proof of Le Fresne's birth when she explains the circumstances to her husband. The identity and purpose of the ring and cloth have stayed relatively the same throughout the journey. The initial giving of the ring and cloth by la dame was with the intention of showing Le Fresne's noble heritage, which is the perception of the doorman, his daughter, and the abbess. In recognizing the artifacts, la dame restores Le Fresne's "identity, purpose, and place in world" (Laskaya and Salisbury 2). The story ends by uniting Le Fresne and Bruron, fulfilling Brewer's "family drama."

The ring and the cloth are not considered by Bruron's men, but they are the artifacts that restore Le Fresne; la dame, however, does not show interest in the tree. These two sets of people choose to focus on specific aspects of Le Fresne's history and heritage. They pick them out amongst many aspects of her life (for example, the cloister, beauty, and education) and allow them to wash over other traits and identifiers. In fact, the character's chosen aspect is augmented in their eyes by making it the sole identifier of Le Fresne. The symbols do not reflect the path of Le Fresne but guide it. The characters have become translators of Le Fresne by assessing and 
interpreting the objects surrounding her. Then using those interpretations, the characters make decisions and judgements that affect Le Fresne as she moves along the story. Le Fresne is the original text and the objects act as the tangible understanding and translation of her.

Granted, Le Fresne, as a human character, does have more agency to speak out against the translations of her than a physical manuscript does. However, in this narrative she chooses not to fight against the understandings of her. She allows the other characters to decide her fate without protest: "Quant ele sot que il le prist, / Onques poior semblant nen fist” (When she learned of the marriage, / She never made any worse expression" (359-60). Though she has more agency, the consequences and costs of these translations are also magnified, as seen when she is taken from the position of lady to Bruron and is demoted to a servant preparing his bride's bed chamber. Also, the objects themselves that define Le Fresne are only significant because of the characters' perceptions of them. The object itsef does not gloss Le Fresne but rather represents the readings being done.

The translation of Le Fresne parallels how translators move texts to the reader; how translators shape the story so to push it in a particular direction that changes the trajectory of the text. The objects and characters cause the reader to view Le Fresne differently as they emphasize particular details of her. Translators do the same with the text as a whole and thus should be noted as active participants in the story. "The translator, far from being an invisible servant of the original text, became its authoritative voice, and the purpose of the translation was in the end not to supplement the original but to 'substitute itself for its source and efface the presence of that source'” (Longard 17). To further investigate this proposal, I will draw upon Rita Copeland's studies in the rhetoric and translational practices of the Middle Ages, Lukas Erne's scholarship concerning the editors of Shakespeare, and Anna Kérchy's understanding of adaptation. 


\section{Collaborative Translators}

Rita Copeland, in "Rhetoric and Vernacular Translation in the Middle Ages" (1987), argues "that medieval vernacular translation is grounded in a historical intersecting of hermeneutical practice with rhetorical theory" (41-42). She sets forth that translation "refigures, through interpretative reception and transference, what has previously been known in a different textual condition" (43). This "transference" of "interpretative reception" from one context to another is a key point. Here, Copeland sets forth, as I do, that the process of translation requires a step of interpretation. To translate effectively the translator needs to know and understand the context or else elements of the text will be hidden in the target text. As seen above, in the inclusion of deduiz and its innuendo, the Middle English and Gilbert translations lack this particular play on words.

The translator encodes the new text, actively or passively, with his/her understanding of the text; "Exegesis ... merges with translation itself as interpretive activity, for the translated text is a hybrid of old and new interpretationes. The translator becomes interpreter, expositor" (Copeland 54). In St. Jerome's letter to Pammachius, he discusses the difficulties of translation: "Like a conqueror [the translator] has led away captive into his own tongue the meaning of his originals" (par. 6). ${ }^{16}$ Jerome highlights the power and active presence the translator bears over a text.

The text has been adjusted by the translator, thus making it accessible to new readers. The "refiguration of language and meaning in antecedent texts" gives clarity to new readers, but also manipulates their interpretational perspectives of the text (Copeland 74). The readers of

\footnotetext{
${ }^{16}$ Ep. 57 to Pammachius, ed. Hilbert, CSEL, 54:512, lines 4-5.
} 
Gilbert's translation are not likely to make the connection between "tasty nuts" and sexual satisfaction as "tasty" is not as common an insinuation of "pleasure." Editions with varying translational choices provide a unique emphasis to the same story.

Lukas Erne, Shakespeare’s Modern Collaborators (2008), argues that Shakespeare's plays are brought to readers collaboratively through the ingenuity of Shakespeare and the work of the editor. Erne notes the other collaborative counterparts of Shakespeare but maintains that the active presence of modern editors may affect reader experiences to a larger degree. He lays out the four forms of collaboration present in Shakespeare's work. First, the actual writing of the plays was collaboration by Shakespeare and others, including George Peele for the play Titus Andronicus and John Fletcher for King Henry VIIII. Second, Shakespeare also worked with his fellow actors and theatrical company:

Long before the play text reached the playhouse, Shakespeare also collaborated with his fellow actors insofar as he wrote certain parts with specific actors in mind and must have partly tailored the parts for their future impersonators. Even the choice of dramatic subject-matter seems to have been partly collaborative, the result of the company's attempt to capitalize on the holdings of rival companies. (2)

Third, Erne also describes the printer's role in influencing the spelling and punctuation and thus visual formation of the written text. Erne's final point is that the modern editor is also a collaborator of the work, "the people who prepare the texts we read in modern editions" (3). The first three groups exerted their influence during Shakespeare's time, while "editors continued to do so to this day" (3). Instead of seeing the editor as a harmful or "harmless drudge," Erne desires us to see the editor as a collaborator (4). The editor should not be seen as a passive reprinter nor as an active klutz, damaging the story with every change. 
Erne's four areas of collaborative-authorship can help readers better understand the authorship of Le Fresne and the work of Marie de France (as a single or collective author). Erne's points one and two are illustrated by the production of the Breton lais. The community that formed the lais involved oral tradition and the minstrels that carried the tradition. As Marie formed the lais, she drew upon this community of people and recontextualized their stories. As the printers changed the trajectory of Shakespeare's publications, so might the scribes of Marie. For instance, "Although Marie de France probably wrote in 'standard' literary Francien with Norman influences, the principal manuscripts of her works were produced by Anglo-Norman scribes" (Kibler 1). This explains why Marie's probable native tongue is not represented in the document. In Erne's argument, the final collaborator is the modern editor, and with Marie's work, I propose that the final collaborator is the translator, broadly construed.

Editors and translators can make significant contributions and changes to texts as we encounter them. A crucial point to understanding the collaboration of the translation is also understanding that each adaptation of a text should be scrutinized for its own worth and not seen as a direct, absolute representation of the original text. Thus, it is understood as a standalone artifact based on its own merits. This point is also made by Anna Kérchy in her discussion, "Alice in Transmedia Wonderland" (2016), which considers Alice in Wonderland (Lewis Carroll $1865)$ and its film adaptations. She asserts that, "Far from being regarded as inferior imitations of the original, adaptations will be interpreted [in her article] as part of an intertextual web where each element ... stand[s] in a dialogic relation with one another, contributing to a dynamic modification of meanings" (9). A translator is given multiple choices in recreating a text, and no representation can fully encapsulate all aspects of the original. A photograph captures the colors and subject but cannot communicate the 3-D nature or sound of the objects; it instead creates a 
lasting impression as it can be preserved over time, but the scene is fleeting. There is a direct relationship between the scene and the photo, but not all aspects correlate, and new aspects are introduced in each representation. Similarly, the Old Norse copy of Le Fresne is written in prose, which loses the rhythmic rhymes but enables a precise translation. Gallagher's translation is prose for this very reason. Gilbert's analogical translation changes the form from octosyllabic couplets to iambic tetrameter. This move maintains the eight-syllable structure but gives the text a distinct rhythm in the English language.

The translational apparatus (for example, collations, emendations, annotations, and genre style) acts as an artifact of Le Fresne. Just as the ring, cloth, and tree identified Le Fresne, so too do these elements give purpose to Le Fresne, the lai. They are the elements being passed along with the main text and provide a particular context to the story. The artifacts surrounding the $L e$ Fresne are chosen by the translators, whereas Le Fresne's objects are determined by the characters around her. The translator is positioning the text in a certain light or angle. The translator is not a passive bystander but is adding to the plot by creating a specific context for the reader. 


\section{CHAPTER IV: A MODEL}

\section{Introduction}

The previous chapter ended with a discussion on the collaborative nature of translations. Here, I would like to consider digital editions and their production in terms of translational practices. Traditionally translated editions give a brief introduction and explanation of the translational practices used on the text, with perhaps a few notations throughout the work to give added context. This method provides a clean representation of the text without a myriad of annotations distracting the reader. Edward Gallagher's translation, The Lays of Marie de France (2010), and Dorothy Gilbert's, Marie de France Poetry (2015), model a clean representation of the lais. Gilbert provides a total of eleven footnotes, with five specifically pertaining to translational choices, while Gallagher's prose translation does not contain any annotation. These two authors each provide a readable translation that gives context to the story but does not drown the reader in linguistic or editorial data.

This approach is excellent for a general readership, but I would like to take this one step further by creating digital editions that allow readers to see the underlining linguistic data, so as to make the translational choices more transparent. The digital medium allows for the manipulation of data in ways that print is not capable of. To demonstrate this goal, I have created my own digital model of Le Fresne that focuses on translational choices. I use the word model because it is not a full-scale edition, but through it, I consider standards and features of digital scholarly editions.

In my model, I provide the grammatical data for each word and allow a space for the viewer to write his/her own translation based on the data provided. Though the linguistic data for words is presented, the information on sentence level structure is not. It is assumed that viewers 
already have an understanding of Old French grammar, and that of present-day English, before coming to this program. This is a limitation of the model; were it expanded it would include a description and introduction to grammatical structures. The grammatical information provided simultaneously invites the user into the translational process but instantly limits or structures his/her reading to what is presented. The user is at the mercy of the editor and the editor's knowledge, understanding, and perception of the content. One possible way to expand the grammatical information would be to link to multiple Old French texts where the same word is used. Lines 121 through 126 were chosen to model the edition because this section of text is the first introduction of the cloth and ring, with these particular lines highlighting the cloth.

121) En un chief d'un molt bel chainsil In an end piece of a very beautiful linen cloth

Envelopent l'enfant gentil

Dedesus d'un paille roé:

Son sire li ot aporté

125) De Costentinoble ou il fu;

Onques si bon n'orent veü.
She wraps the noble child

Within a silk and gold threaded cloth with round designs:

Her husband had brought it

From Constantinople where he was;

Never such a good cloth had anyone seen.

Though this may seem an uninteresting section to highlight translational choices, it does illustrate how even seemingly straightforward passages may be translated in multiple ways.

For instance, roé, a three-letter word with no clean-cut translation to English, is defined by William Kibler, An Introduction to Old French (1984) as wheel or round shaped, while Alan Hindely et. al., Old French-English Dictionary (2000), add floral or ring patterns to the definition. A wheel-design translation might limit the American English readers because wheels 
are also an industrial mechanism. Thus, that connotation might evoke dirt, grime, and movement, instead of the elegance and softness that a floral design might suggest. Gallagher uses the word circular to describe the design in his translation (22). Circular gives a general idea of an abstract design that is less specific than a wheel or floral design. In contrast, Gilbert ${ }^{17}$ describes the cloth as striped, "all around / a striped brocade placed over [the linen wrap]" (122-3). But, given Byzantine silks that have survived, a circular design is a more accurate description than striped. For instance, the Byzantine silk Annunciation (circa eight to ninth century) has circular frames surrounding depictions of Gabriel visiting Mary (held at the Vatican Museums, Vatican City). The Sēnmurw Silk (circa seventh to eighth century) also uses a circular frame pattern around a mythical creature (kept at the Victoria \& Albert Museum, London). Though the model does not include it, to better expand the user's understanding of roé, images of these textiles and other typical Byzantine silks would provide a much better context to the design than relaying fully on a verbal description.

This short discussion of roé illustrates the variations and implications of what might seem a straightforward translational choice, proving that presumed "minor" translational choices are never minor and that each choice has depth. For this reason, I have created a digital model of $L e$ Fresne so to illustrate the possible depth of the text to readers. Granted, the level of transparency

${ }^{17}$ It should be noted that Gilbert based her translation on the Harley manuscript, which is in Anglo-Norman, while Gallagher's and my translation are based on the Old-French manuscript held at the Bibliothèque Nationale de France. It could be that roé is an emendation created in the Old French manuscript. 
provided by the model is still very shallow as only the synonyms are displayed and not a comparative analysis for each word as seen above for roé.

\section{The Model}

The primary text guiding this model is the MLA Statement on the Scholarly Edition in the Digital Age (2015). (The eight criteria for a scholarly edition and four for the digital editions are given at the beginning of chapter two. These specifications will be referred to throughout this chapter.) The model I have created has a simple design, written in Calibri font on a white background (see figure 9 for an image of the "Welcome" page). The grayscale is used for most features including the parsing buttons and navigation bar. The only color present is a dark aqua used to differentiate the three non-parsing buttons. This minimalistic approach allows for clear readability.

Translating Le Fresne

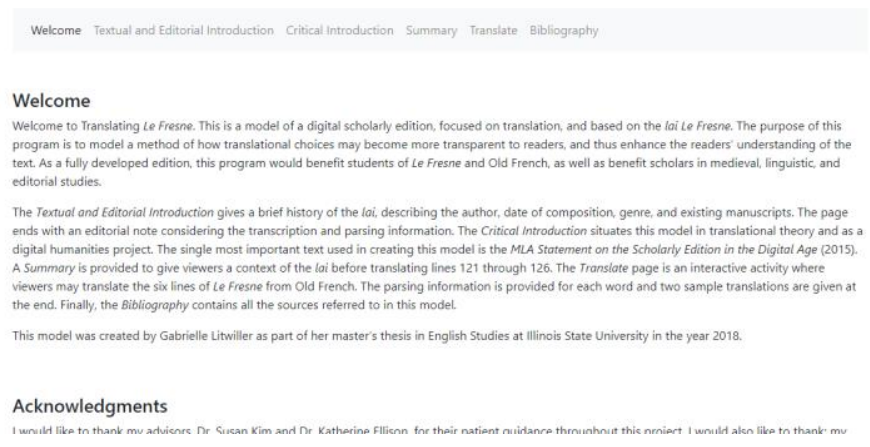

Figure 9. An image of the "Welcome" page, demonstrating the design and layout of the model 
Four pages of the program provide a context to the model and the lai. The "Welcome" page briefly explains the purpose of the edition and describes the layout and information that can be found on the other pages. As explained above, the goal of the program is to be a model of how to make translational choices more transparent to readers so that the richness of the original text might pull through to the target language. Including the purpose of the model on the "Welcome" page fulfills the sixth point in the MLA Statement, which asks that the goals of the edition are stated. The "Welcome" page gives a concise explanation of the purpose, with the "Critical Introduction" explaining the methodology of this goal.

To fulfill the majority of the MLA Statement conditions for a scholarly edition, the model contains a textual and editorial introduction and a critical introduction. Initially, I summarized the research and theoretical conclusions discussed in chapters two and three. However, in doing so too much of the research was glossed over and an understanding of the scholarly landscape was neglected. After considering the Electronic Beowulf (EB) digital scholarly edition, I sought to be more explicit about the relevant research. To correct the balance between concision and explanation of conclusions, I explicitly included the primary resources that influenced my work. This makes apparent to viewers the justification for various decisions and developments to produce the model (thus addressing the first, second, third, and fourth concern for scholarly editions in the MLA Statement).

I also include a bibliography page for the resources mentioned in the model. The bibliography is presented to cite the information given, but also to encourage further study in the field. To further develop the project, a selected bibliography would also be given and organized by topics (such as Le Fresne, Old French, Translation Theory, and Digital Humanities) so to assist viewers and further the research begun here. The bibliography is coded in a similar way as 
the one present on the Piers Plowman Electronic Archive (PPEA), which also appears as a bulleted list.

The textual and editorial introduction, including information on the identity of Marie and the existing manuscripts of the lai, is placed immediately after the "Welcome" page so to give a context for the viewers who may know little about $L e$ Fresne. With the basic information explained, the following pages and discussions are more easily understood. The inclusion of the textual and editorial introduction addresses the seventh desire of the MLA Statement, that "it should contain a detailed textual introduction or editorial policy statement, as distinguished from a critical introduction, that outlines these aspects" (7). This model does move slightly from the guidelines of the MLA Statement, as the justifications and research are spread over the textual and critical introduction. I have divided the information because I believe students will need the explanations found in the textual introduction before proceeding to the text, but I do not anticipate the student audience having as much desire for the information provided in the critical introduction as scholars might.

An editorial note (addressing point two and seven of the MLA Statement) is given at the bottom of the page describing the edition used for this model, which is by William Kibler, An Introduction to Old French (1984). Kibler's edition is based on the manuscript of Le Fresne held at the Bibliothèque Nationale de France, "and departs from it only where that manuscript is manifestly less satisfactory" than the Harley (294). However, Kilber does not state what accounts for an unsatisfactory transcription. The departures amount to a total of forty-seven emendations, though none are present in the lines selected for the model. In this instance, I am relaying on Kibler's edits and his interpretation of the narrative and physical manuscript, and this reliance exposes another translational level not addressed in the model. The physical understanding of the 
manuscripts with erasures, smudges, damage, etc., is another point of understanding and translating the text. This model could expand with this in mind by including high resolution images of the manuscript, much like the EB project.

A brief description of the coding used to create the model is given in the editorial note, as that also is a form of editing. The portion of the lai presented in the model is coded in TEI, as TEI is preferred by digital humanities scholars (see chapter two for a larger explanation of TEI). So to further the study of Le Fresne and allow for the "sampling, reuse, and remix" of the digital model, I have created a downloadable file of the Old French lines and the parsing information (MLA Committee 7). This fulfills some of the longevity concerns laid out by the MLA Statement (point eight of the scholarly criteria and points two and three of the digital concerns). The TEI tags various data points, such as lines and rhymes, so that the computer can recognize those features. For examples of TEI coding see figure 10 for the code of the poem and figure 11 for the coding of the word un found in line 121. Once the features are defined, the computer can search and manipulate those points. In contrast, HTML is used to render and display the data in a way that human eyes can understand and quickly process. JavaScript and jQuery are also used and make the data interactable. This interaction is a key point in the model because it is through the interaction that viewers can see the underlying layers to the words. TEI, HTML, JavaScript, and jQuery are all coding languages that emphasize and relay different aspects of the data. This project needs layers of languages to fully express the data as no single language will entirely render and display the information.

The critical introduction locates the model within translation theory and as a digital humanities project, giving a context to the decisions in the creation of the model. The information and research provided on this page is a very brief overview of the discussions in 
chapters two and three, including the data concerning the survey of commercial digital resources. In a future expansion of this model, the $\mathrm{Q}$ tag (as discussed in chapter two) would be added so to understand the use of tools and features of the edition. This would be in an effort to further study students' approaches to literary texts and the learning tools that are most effective for them. The Q tag cannot be added to this

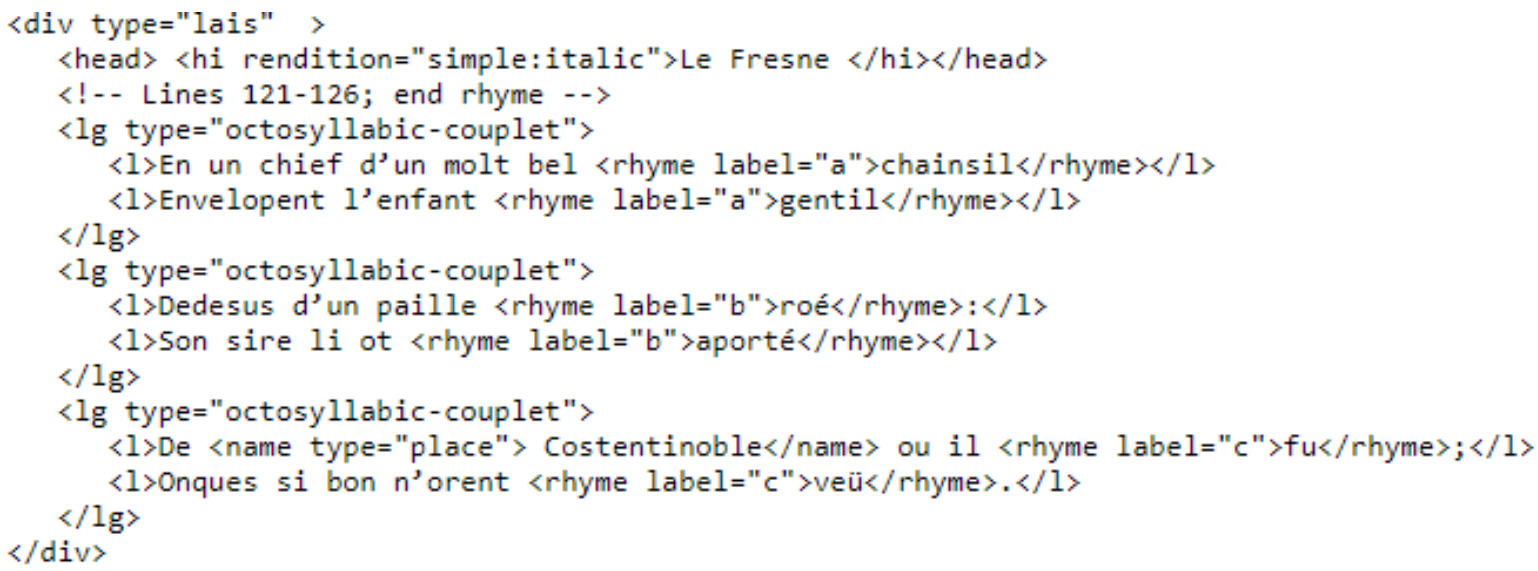

Figure 10. The TEI code for lines 121-126

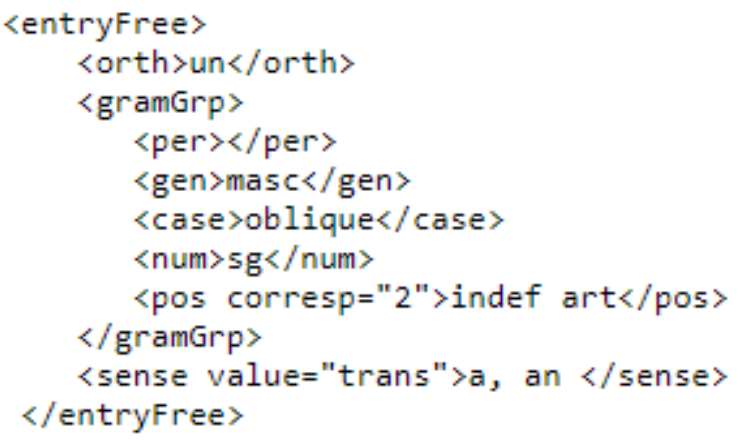

Figure 11. The TEI code for the parsing of $u n$ 
model because it is not uploaded to a server and available on the web. I have chosen to leave the program as a file because it is a model and not a fully developed edition.

A summary appears before the translation activity to provide a context for those unfamiliar with the lai. I have included a summary of Le Fresne in the model because of the research on student use and desire for comprehension (this is discussed in chapter two). Because only a small portion of the lai is presented, a context is necessary for the users to understand what is being translated and how it fits within the greater narrative.

The "Translate" page is where all this information, preparation, and research is put into practice. This page provides the space in which the fifth point of the MLA Statement can be fulfilled, concerning a "rigorous standard of accuracy and consistency in applying" the methods (7). Sample translations of the lines are given at the bottom of the exercise. Two translations in differing styles were chosen so that users may contrast the styles and choices. The poetic style is represented by Gilbert's translation and the prose is written by Gallagher. In Gallagher's translation the word for word meaning is better understood, but Gilbert's work represents the text as a poetic style, relaying the rhythm and movement of the words. These translations are programmed to toggle open in a dropdown, instead of showing as plain text, so that users are less tempted to look at the samples while they are creating their own translations. The intent of the sample translations is to encourage students in their translation. This again echoes back to the information gathered in the survey of chapter two in regards to the delicate balance of encouraging rather than foreclosing interpretation.

The "Translate" page is organized in three distinct parts, the Old French transcription, the parsing of each word, and the compiled translation by the user. It was created in these parts to 
ease readability. This way the viewer is not interrupted in reading the poem with the parsing buttons and submission input and can instead read the poem seamlessly at the beginning. The translation by the user is also compiled at the end for this reason. This organization works well for such a small section of text. But, were this project to be expanded to the full-text, it would be better to represent these sections (and sample translations) on separate pages.

In addition to the sample translation buttons, I have set the parsing buttons to toggle and not hover so that the popups may remain viewable. This can create a messy interface; however, I have chosen this so that viewers can view multiple words at once. This may be helpful when considering the proper grammar or syntax, especially with words that work together, such as onques and $n e$ in the final line of the model, which are separated by the words si bon (126).

The longevity of an edition is a primary concern of the MLA Statement (point eight of the scholarly criteria and point two of the digital criteria). The simple design was chosen to make it easily adaptable in new digital contexts. The design also makes it suitable for use on varying devices. For instance, it appears well on slightly larger devices, such as tablets or computers. It is also readable on phones, though not ideal. Figures 12 and 13 show a portion of the "Translate" page as seen on a Pixel 2 phone. Figure 12 illustrates the readability of the file on such a small device, though highlights a potential weakness by having the parsing for a single line spill into two lines, instead of being programmed to render as smaller buttons. Figure 13 illustrates the primary flaw in which the poetic example does not expand horizontally, making it impossible to see the poetic structure. However, this view is remedied when both samples are displayed at one time, filling the horizontal space as Gilbert is stacked on top of Gallagher. 


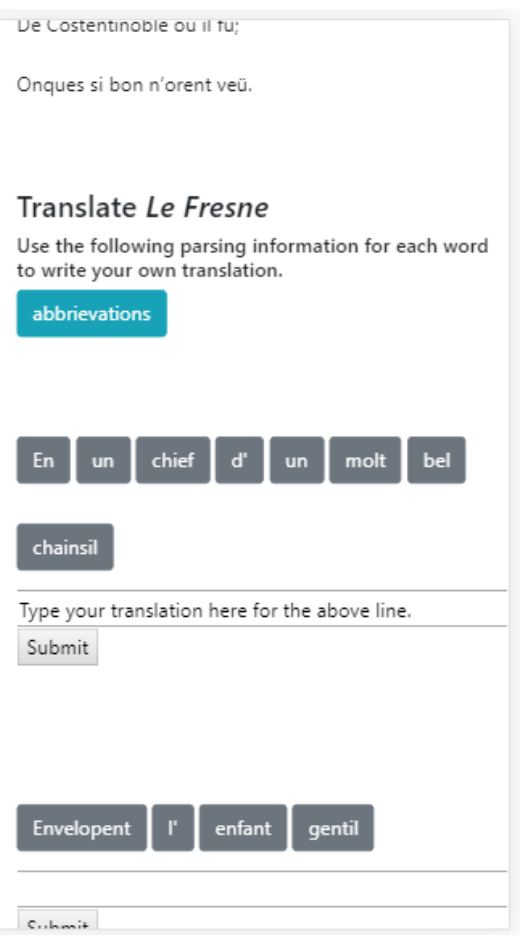

Figure 12. The model as seen on a Pixel 2 phone 
Compare your translation to others:

Poetic Prose

In a fine linen

wrap, they wound

the lovey baby; al

around

a striped brocade

placed over that:

a gift the lady's

husband brought

from

Constantinople,

where he' $d$ been:

never was one

more splendid

seen!

Dorothy Gilbert,

Marie de France

Poetry

Figure 13. The model as seen on a Pixel 2 phone with rendering flaw

The third point of digital criteria in the MLA Statement is concerned in "maintaining the scholarly ability to be referenced in view of the ways that interfaces change over time" (7). The pages of this model are separate files of information which aid in keeping all the information locatable (for instance in a browser the location ends in "translate.html" and "summary.html"). This is unlike the EB, which maintains the same URL throughout navigation of the program, http://ebeowulf.uky.edu/ebeo4.0/CD/main.html. Though the model files are not URLs, their file names keep them unique. To additionally address point three of the digital concerns, as well as point three of the scholarly criteria, the TEI coding standards include a revision history to appear at the top of the coding page (see figure 14 for the short revision history of the TEI code). However, I have coded only the lai and parsing information in TEI and not the contextual 


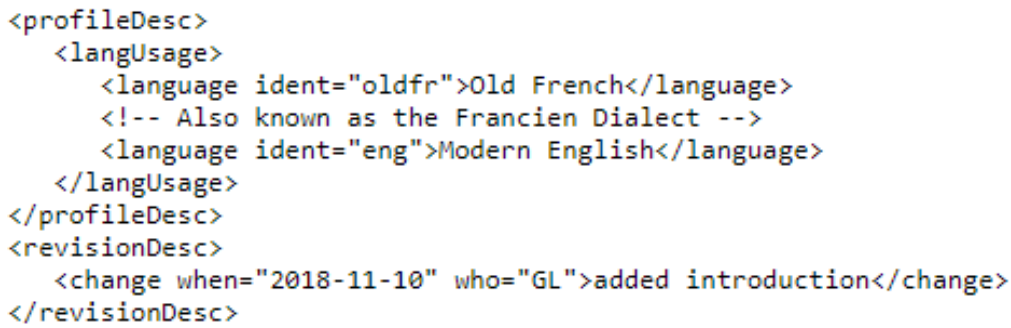

Figure 14. The language and revision description of the TEI code

information. Thus, my model is weak in describing the updates over time to the program on other files, such as the bibliography.

One last aspect concerning the longevity of an edition is made in the fourth point of the digital criteria and is concerned that the edition "should attempt to balance considerations for intellectual property and labor with the goals of achieving open access and reusability" (8). I have added a Creative Commons License to the model to address this. The license allows for the program to be redistributed with credit given to the creator and used non-commercially, making this a freely available resource.

\section{Conclusion}

This model could be expanded in multiple ways. First and foremost, the full-text of $L e$ Fresne is needed. To go a step beyond this, a transcription of all four manuscripts would vastly improve the resource for scholars. More introductory pages would also be helpful, for instance, an explanation of Old French grammar. As the program is designed here, it is assumed that the viewer understands the appropriate grammatical structure. To also assist users in grammatical 
choices, a built-in tool that checks the Old French grammar, much like a spell checker, may also benefit students using the program to study Old French. It may also aid students to have a brief discussion of possible translational choices (for example rhyming schemes and poetic structures) to choose from when creating their own translations. As the project expands, so would the navigation need to expand. For instance, the inclusion of a search function may be convenient especially for those doing word studies. Also, a side navigation bar may prove helpful when navigating individual pages.

One deficit of the model as it is designed here is that there is no way to contact those working on the project. PPEA simply offers an email address for questions, comments, or technical issues. Another crucial consideration for expansion would be the inclusion of alternate text in the code, especially for images or links, as this would aid in the navigation for those visually impaired.

This chapter along with the introductory material in the model makes transparent the data and articulates the motives while considering the longevity of such a model and project. The MLA Statement is the guiding text to the project, with sample digital editions such as the EB and PPEA also sharing input and wisdom. To create this model Le Fresne first needed to be translated into coding languages before being translated by the viewer, thus creating multiple layers of translation. The next chapter will conclude the project. 


\section{CHAPTER V: CONCLUSION}

The process by which translated texts are mediated to scholars and, in particular, students is the central concern of this project. The lai Le Fresne itself has been translated multiple times in its early history, establishing multiple instantiations of the process of translation from one culture and context to another. As I trace out these instances of translation, I also engage in another kind of translation through the process of creating the model of a digital edition. A segment of the text is also translated into code here, in the model, so that it can be understood digitally. Though the viewer does not see the coding, it is an underlining mediation to the digital edition.

Through Le Fresne, the character, the reader sees the effect of translation through the ring, cloth, and tree. The objects provide a structure and means by which Le Fresne is translated; they add a specific context which is then used to interpret Le Fresne's identity. Likewise, the surrounding objects used to create an edition, including annotations, emendations, critical and textual introductions, provide a context for Le Fresne to be understood by modern readers. Even the model I have created and encoded is an object to the lai. The parsing and translation choices that are given in the model guide the viewer to understand the text in a specific way even as it invites the viewer to take part in the process.

Editors and translators create and attach objects to their editions. They are like la dame and the abbess who give Le Fresne the artifacts and the name. The artifacts and objects are the means by which the characters of Le Fresne interpret Le Fresne. Through an edition the text itself is understood through the surrounding matter (such as annotations and critical introductions), creating a unique read of the narrative. The translators of editions situate the text based on their understanding and knowledge. Because surrounding matter can be influential in 
interpreting the text, more study is needed to better understand the use of digital editions by students. Thus, more transparent mediation of the text for the student can be done when building future digital scholarly editions.

As I study Le Fresne and the movement of characters and objects, I wonder what objects attached to me are being translated and read by others. 


\section{REFERENCES}

"A Brief History of SparkNotes.” SparkNotes. 2018, www.sparknotes.com/about/history/. Accessed 17 Feb. 2018.

"About CliffsNotes." CliffsNotes. www.cliffsnotes.com/discover-about. Accessed 3 Feb. 2018. Brewer, Derek. Symbolic Stories. Boydell \& Brewer, 1980.

Burns, E. Jane. "Saracen Silk: Dolls, Idols, and Courtly Ladies." Courtly Love Undressed. U of Pennsylvania P, 2002. pp. 181-210.

Carruthers, Leo. "What Makes Breton Lays 'Breton'? Bretons, Britons and Celtic 'Otherness' in Medieval Romance." Études Épistémè. Revue de Littérature et de Civilisation (XVIeXVIIIe siècles), no. 25, 4 Jan. 2014, OpenEdition, doi:10.4000/episteme.205.

“Character Map.” Beowulf. CliffsNotes, www.cliffsnotes.com/literature/b/beowulf/charactermap. Accessed 26 Oct. 2018.

Clifford, Paula. Marie De France Lais. Grant \& Cutler Ltd., 1982. Critical Guides to French Texts Series.

Cook, Robert, and Mattias Tveitane. Strengleikar. Kjeldeskrift-Institutt, 1979. Norrøne Tekster Series: 3 .

Copeland, Rita. "Rhetoric and Vernacular Translation in the Middle Ages." Studies in the Age of Chaucer, vol. 9, 1987, pp. 41-75. Project Muse, doi:10.1353/sac.1987.0001.

Copland, Colleen, et al. "Kiernan, Kevin S. 2015. Electronic Beowulf - Fourth Edition. Http://Ebeowulf.Uky.Edu/Ebeo4.0/CD/Main.Html.” Digital Medievalist, vol. 10, 27 Sept. 2016. doi:10.16995/dm.56.

Duggan, Hoyt N., and Eugene W. Lyman. "A Progress Report on the Piers Plowman Electronic Archive." Digital Medievalist, vol. 1, 20 Apr. 2005. doi:10.16995/dm.5. 
Duggan, Hoyt, et al. Piers Plowman Electronic Archive. Society for Early English and Norse Electronic Texts (SEENET), 8 Mar. 2018, piers.chass.ncsu.edu.

Erne, Lukas. Shakespeare's Modern Collaborators. Continuum, 2008. Shakespeare Now! Series.

Estrellas, et al. "Should I use SparkNotes?" College Confidential, 5 Aug. 2013, talk.college confidential.com/high-school-life/1537526-should-i-use-sparknotes.html. Accessed 25 Oct. 2018.

Fargen, Jessica. "IDG Books Worldwide Buys CliffsNotes." The Daily Nebraskan, 9 Dec. 1998, www.dailynebraskan.com/idg-books-worldwide-buys-cliffs-notes/article_c4c949c7b1ae-51fb-8058-afbb23fc90ff.html.

Furchgott, Roy. "A Professor Reviews CliffsNotes and Other Cheat Sheets." The New York Times, 15 Sept. 2010, www.nytimes.com/2010/09/16/technology/personaltech/16basics. html.

Gallagher, Edward. The Lays of Marie De France. Hackett Publishing Co., 2010.

Gilbert, Dorothy. Marie De France Poetry. W. W. Norton \& Co., 2015.

Goeres, Erin Michelle. "Sounds of Silence: The Translation of Women's Voices from Marie De France to the Old Norse Strengleikar." The Journal of English and Germanic Philology, vol. 113, no. 3, July 2014, pp. 279-307. JSTOR, doi:10.5406/jenglgermphil.113.3.0279.

"Help." SparkNotes. 2018, www.sparknotes.com/help/. Accessed 2 Feb. 2018.

Hindley, Alan, et al. Old French - English Dictionary. Cambridge UP, 2004.

"Jacinth Gemstones." Gem Select. SETT Company Ltd., 16 Aug. 2017, www.gemselect.com/ other-info/jacinth-gems.php. Accessed 21 Sep. 2018. 
Jerome. "Letter 57." New Advent, edited by Kevin Knight, 2017, www.newadvent.org/fathers/ 3001057.htm. Accessed 29 Sep. 2018.

Jones, Francis R. "The Translation of Poetry." The Oxford Handbook of Translation Studies, edited by Kirsten Malmkjær and Kevin Windle, Oxford Handbooks Online / Oxford UP, Sep. 2012, pp. 169-182. doi:10.1093/oxfordhb/9780199239306.013.0013.

Kérchy, Anna. "Introduction: Adapting Ambiguous Alice." Alice in Transmedia Wonderland, McFarland \& Co., 2016. pp. 3-26.

"Kevin Kiernan." U of Kentucky College of Arts \& Sciences: English, english.as.uky.edu/users/ kkiernan. Accessed 19 Oct. 2018.

Keyser, Rudolph, and Carl Richard Unger. Strengleikar Eða Lioðabok. 1850. HathiTrust, babel.hathitrust.org/cgi/pt?id=mdp.39015030066412;view=1up;seq=1. Accessed 29 May 2018.

Kibler, William W. An Introduction to Old French. Modern Language Assn. of America, 1984. Introductions to Older Languages Series: 3.

Kiernan, Kevin, and Emil Iacob. Electronic Beowulf. $4^{\text {th }}$ ed., British Library / U of Kentucky, 2015. ebeowulf.uky.edu. Accessed 6 Feb. 2018.

Kiernan, Kevin, et al. "Electronic Beowulf Archives, 1993-1997." U of Kentucky. U of Kentucky, www.uky.edu/ kiernan/eBeo_archives/\#top. Accessed 27 Jan. 2018.

Kline, Diana. "My Generation Essay: SparkNotes: A Way to Cheat or Learn?" Pittsburgh PostGazette, 23 Dec. 2014. www.post-gazette.com/life/my-generation/2014/12/24/MyGeneration-Essay-SparkNotes-a-way-to-cheat-or-learn/stories/201412240072.

Laskaya, Anne, and Eve Salisbury. The Middle English Breton Lays. Medieval Inst. Publ. / Western Michigan U, 1995. TEAMS Middle English Texts Series. 
Longard, Jeffrey. "Making Your Memory Mine: Marie De France and the Adventures of the Bretons." TranscUlturAl, vol. 8, no. 1, U of Alberta, 1 July 2016, pp. 17-37.

McCash, June Hall. "Sidney Painter (1902-1960): The Issue of Patronage for Marie De France." The Reception and Transmission of the Works of Marie De France, 1774-1974, edited by Chantal Marechal, vol. 23, The Edwin Mellen Press, 2003, pp. 171-203. Mediaeval Studies Series.

Mickel Jr., Emanuel J. Marie De France. Twayne Publ., 1974. Twayne's World Authors Series. MLA Committee of Scholarly Editions. "MLA Statement on the Scholarly Edition in the Digital Age." MLA, Modern Language Assn., May 2016. www.mla.org/Resources/Research/ Surveys-Reports-and-Other-Documents/Publishing-and-Scholarship/Reports-from-theMLA-Committee-on-Scholarly-Editions/MLA-Statement-on-the-Scholarly-Edition-inthe-Digital-Age.

Nelson, Deborah. "The Implications of Love and Sacrifice in 'Fresne' and 'Eliduc."” The South Central Bulletin, vol. 38, no. 4, Winter 1978, pp. 153-5. JSTOR, doi:10.2307/3187389.

Olsen, Kenna L. "Calabrese, Michael, Hoyt N. Duggan and Thorlac Turville-Petre, Eds. 2008. the Piers Plowman Electronic Archive Vol. 6: San Marino, Huntington Library Hm 128 (Hm, Hm2). and Adams, Robert, Ed. 2011. the Piers Plowman Electronic Archive Vol. 7: London, British Library, MS Lansdowne 398 \& Oxford, Bodleian Library, MS Rawlinson Poetry $38(R)$. Cambridge: Published for the Medieval Academy of America and the Society for Early English and Norse Electronic Texts by Boydell \& Brewer. CD-ROM." Digital Medievalist, vol. 7, 9 Feb. 2012. doi:10.16995/dm.31.

Quantcast. 2018, www.quantcast.com. 
Ousterhout, Robert. "Looking East from Constantinople: Byzantium and Silk Road.” Penn Museum, 4 May 2011, www.penn.museum/collections/videos/video/986.

Reid, Calvin. "Wiley Offers Cliffs Notes Free Online." Publishers Weekly, 6 Sep. 2004, www.publishersweekly.com/pw/print/20040906/21758-wiley-offers-cliffs-notes-freeonline.html.

Rikhardsdottir, Sif. "The Imperial Implications of Medieval Translations: Old Norse and Middle English Versions of Marie De France's Lais." Studies in Philology, vol. 105, no. 2, Spring 2008, pp. 144-164. JSTOR, www.jstor.org/stable/20464314.

Shippey, Thomas A. "Breton Lais and Modern Fantasies." Studies in Medieval English Romances: Some New Approaches, edited by Derek Brewer, Boydell \& Brewer, 1988, pp. 69-91.

Simpson, Grant Leyton. "Kiernan, Kevin. 2011. Electronic Beowulf 3.0. London: British Library. DVD-ROM. ISBN 9780712351010. \$45/£25." Digital Medievalist vol. 8, 11 Feb. 2013. doi:10.16995/dm.47.

"TEI: Guidelines." Text Encoding Initiative. www.tei-c.org/guidelines/. Accessed 30 Oct. 2018.

"TEI: History." Text Encoding Initiative. http://www.tei-c.org/about/history/. Accessed 23 Oct. 2018.

"Wiley to Acquire Hungry Minds." Wiley, John Wiley \& Sons, Inc., 13 Aug. 2001, www.wiley.com/WileyCDA/PressRelease/pressReleaseId-48782.html.

Wisdom, Stella. "Electronic Beowulf 4.0." Digital Scholarship Blog. British Library, 13 Oct. 2015, blogs.bl.uk/digital-scholarship/2015/10/electronic-beowulf-40.html. Accessed 19 Oct. 2018. 
"Zircon Gemstone." Gem Select. SETT Company Ltd., 18 Oct. 2017. www.gemselect.com/geminfo/zircon/zircon-info.php. Accessed 27 Sep. 2018. 


\section{APPENDIX A: MANUSCRIPTS OF LE FRESNE}

\section{Anglo-Norman c. mid- $13^{\text {th }}$ century}

Of the manuscripts containing Marie's lais, MS Harley 978, housed at the British Library, ${ }^{18}$ is considered the authoritative copy of the lais and is often used for modern editions because it contains all the lais as well as the fables (Cook and Tveitane xx; Gilbert xv). Marie's probable native tongue is not represented in the document: "Although Marie de France probably wrote in 'standard' literary Francien with Norman influences, the principal manuscripts of her works were produced by Anglo-Norman scribes." (Kibler 1). Also, the document comes about a hundred years after Marie and the stories would have circulated within the Anglo-Norman language and could have lost Francien features.

\section{Old French c. mid-13 ${ }^{\text {th }}$ century}

The Old French manuscript was written in the Francien dialect, which was located in the Ile-de-France region and included Paris, in the mid- $13^{\text {th }}$ century. This manuscript is at the Bibliothèque Nationale de France. ${ }^{19}$ I use William Kibler's transcription of the Old French, An Introduction to Old French (1984), but the translation is my own.

${ }^{18}$ The British Library has digitized the Harley MS 978 (Marie's lais are ff. 40-67v, 118r-160r) and images are available on the website.

${ }^{19}$ The manuscript catalogue number for all of Marie's lais is MS fr 24432, and according to Kibler, Le Fresne specifically is at: f. fr. 1104, folio 39v. However, I have had difficulty in tracking down Le Fresne at the Bibliothèque's website myself. 


\section{Old Norse c. late $13^{\text {th }}$ century}

The Old Norse version of Le Fresne, titled Eskia, is found in the Strengleikar collection; "Strengleikar is now largely contained within one manuscript, Uppsala University Library, de la Gardie 4-7. Dating from around the year 1270 and likely produced in Bergen or the surrounding area" (Goeres 281). The Norwegian King, Hákon Hákonarson (born 1204), reigned from 1217 to 1263 and commissioned the de la Gardie because of his fascination with the Anglo-Norman court (Goeres 282-3; Rikhardsdottir 146). This interest illustrates the politics of the day and "the lively environment of cultural exchange that took place between Scandinavia, England, and France during the twelfth and thirteenth centuries" (Goeres 282). Hákon restored peace and culture to Norway by bringing to an end the civil wars that had lasted over one hundred years.

After restoring peace, he sought to reestablish the court's prestige. The Scandinavian interest in Marie de France's work and other notable Anglo-Norman and French work was to emulate their court and thus bring stability and artistry to Hákon's court (Rikhardsdottir 147): “ $<$ E $>$ n bok Pessor er hin $n$ virđulege hacon konongr let norrœna or volsko male ma hæita liođa bok." (This book, which the esteemed King Hákon had translated into Norse from the French language, may be called 'Book of Lais' ...) (Strengleikar Prologue, translated by Cook and Tveitane 5). Though Hákon commissioned the Strengleikar, it was written during his son’s reign, King Magnús Lagaboetir (Cook and Tveitane xv). Although only one name, Bróðir Robert, is given within the collection, Robert Cook and Mattias Tveitane, Strengleikar (1979), identify three distinct hands (Cook and Tveitane $\mathrm{x})$ :

The identity of this "Brother Robert" is uncertain, although it has been suggested that he was an Anglo-Norman cleric working at the Norwegian royal court. It may be, however, that he was merely one of several translators, as the most recent editors of the collection 
observe: different lais seem to have been translated into a variety of Old Norwegian dialects, while the adaptation of the French sources varies considerably from one tale to the next. The de la Gardie manuscript may well represent the first time these particular lais were brought together in one compilation. (Goeres 281)

Though the Strengleikar is a later copy, Cook and Tveitane doubt if it was copied from the Harley or the Bibliothèque Nationale de France. Instead, they trace the linguistic aspects of the Strengleikar to East Norwegian (Cook and Tveitane xxiv; Goeres 282). I use Cook and Tveitane's transcription and translation when quoting the Old Norse text.

\section{Middle English c. early $14^{\text {th }}$ century}

The MS Auchinleck, housed in the National Library of Scotland Advocates, contains the only Middle English translation of Le Fresne (spelled Freine) and is dated to 1330. "The dialect features of Le Freine are Southern with some East Midland elements" (Laskaya and Salisbury 61). I use Anne Laskaya and Eve Salisbury's edition, The Middle English Breton Lays (1995), for the Middle English transcriptions. 
APPENDIX B: SURVEY DATA

Data on Commentaries of the Use of SparkNotes (SN) and CliffsNotes (CN)

Table B-1. Commentary Description

\begin{tabular}{|c|c|c|c|c|c|c|c|c|c|}
\hline \multirow{3}{*}{$\begin{array}{l}\text { Author of } \\
\text { Commentary }\end{array}$} & \multicolumn{5}{|c|}{ Author's Status } & \multicolumn{3}{|c|}{ Type of Publication } & \multirow[t]{3}{*}{$\begin{array}{l}\text { Description of } \\
\text { Discussion }\end{array}$} \\
\hline & \multirow[t]{2}{*}{ Teacher } & \multicolumn{3}{|c|}{ Student } & \multirow[t]{2}{*}{ Reporter } & \multirow[t]{2}{*}{ Forum } & \multirow[t]{2}{*}{$\mathrm{B} \log$} & \multirow{2}{*}{$\begin{array}{l}\text { News } \\
\text { Article }\end{array}$} & \\
\hline & & $\begin{array}{l}\text { High } \\
\text { School }\end{array}$ & College & Unknown & & & & & \\
\hline Anonymous & & & & terater & & $\mathrm{x}$ & & & $\begin{array}{l}\text { Do teachers know when } \\
\text { students use study } \\
\text { guides? }\end{array}$ \\
\hline Dotzenrod & $\mathrm{x}$ & & & & & & & $\mathrm{x}$ & $\begin{array}{l}\text { Use in the classroom and } \\
\text { cheating }\end{array}$ \\
\hline Estrellas & & $\mathrm{x}$ & & & & $\mathrm{x}$ & & & How to study \\
\hline Furchgott & & & & & $\mathrm{x}$ & & & $\mathrm{x}$ & $\begin{array}{l}\text { Review of common } \\
\text { study guides }\end{array}$ \\
\hline Gallagher & $\mathrm{x}$ & & & & & & $\mathrm{x}$ & & Use in the classroom \\
\hline Gorte & & $\mathrm{x}$ & & & & & & $\mathrm{x}$ & Pros and Cons of SN \\
\hline Greatone1 & & & $\mathrm{x}$ & & & $\mathrm{x}$ & & & Is $\mathrm{SN}$ enough to pass \\
\hline Hamblin & $\mathrm{x}$ & & & & & & & $\mathrm{x}$ & Studying with SN \\
\hline Invoyable & & & & $\mathrm{x}$ & & $\mathrm{x}$ & & & $\mathrm{SN}$ vs CN \\
\hline Kline & & & & $\mathrm{x}$ & & & & $\mathrm{x}$ & Is $\mathrm{SN}$ cheating? \\
\hline Vogel & & & $\mathrm{x}$ & & & & & $\mathrm{x}$ & $\begin{array}{l}\text { SN should be an } \\
\text { acceptable tool }\end{array}$ \\
\hline Yao & & $\mathrm{x}$ & & & & & & $\mathrm{x}$ & $\mathrm{SN}$ is helpful \\
\hline
\end{tabular}

Table B-2. Study Guide Tools

\begin{tabular}{|c|c|c|c|c|c|c|}
\hline \multirow[b]{2}{*}{$\begin{array}{l}\text { Author of } \\
\text { Commentary }\end{array}$} & \multicolumn{6}{|c|}{ Tools and information mentioned that are offered by study guides } \\
\hline & Summaries & Quizzes & $\begin{array}{l}\text { Themes and } \\
\text { symbols explained }\end{array}$ & $\begin{array}{l}\text { No Fear Translation } \\
\text { by SN }\end{array}$ & Analyses & Other \\
\hline Anonymous & $\mathrm{x}$ & & & & & \\
\hline Dotzenrod & & $\mathrm{x}$ & & $\mathrm{x}$ & & \\
\hline Estrellas & $\mathrm{x}$ & & $\mathrm{x}$ & & & \\
\hline Furchgott & & & & & & CramCast by CliffsNotes \\
\hline Gallagher & $\mathrm{x}$ & & $\mathrm{x}$ & $\mathrm{x}$ & $\mathrm{x}$ & \\
\hline Gorte & $\mathrm{x}$ & & & & $\mathrm{x}$ & \\
\hline Greatone1 & & & & & & Facts \\
\hline \multicolumn{7}{|l|}{ Hamblin } \\
\hline Invoyable & $\mathrm{x}$ & & & & & glossary, critical essays \\
\hline \multicolumn{7}{|l|}{ Kline } \\
\hline Vogel & $\mathrm{x}$ & & & & & \\
\hline Yao & $\mathrm{x}$ & $\mathrm{x}$ & & & & Flash cards, Spark Charts \\
\hline
\end{tabular}


Table B-3. Study Guide Pros

\begin{tabular}{|c|c|c|c|c|c|}
\hline \multirow[b]{2}{*}{$\begin{array}{l}\text { Author of } \\
\text { Commentary }\end{array}$} & \multicolumn{5}{|c|}{ Pros of Study Guides } \\
\hline & Comprehension & Free & $\begin{array}{l}\text { Quick } \\
\text { Read }\end{array}$ & $\begin{array}{l}\text { Compare and clarify student's } \\
\text { thoughts to the study guides }\end{array}$ & Others \\
\hline Anonymous & $\mathrm{x}$ & $\mathrm{x}$ & & & \\
\hline Dotzenrod & $\mathrm{x}$ & & $\mathrm{x}$ & & \\
\hline Estrellas & & & & $\mathrm{x}$ & \\
\hline Furchgott & & $\mathrm{x}$ & & & Stimulate thought \\
\hline Gallagher & $\mathrm{x}$ & & $\mathrm{x}$ & & $\begin{array}{l}\text { No Fear Translation provided more } \\
\text { enjoyment of the text. }\end{array}$ \\
\hline Gorte & $\mathrm{x}$ & & $\mathrm{x}$ & & \\
\hline Greatone1 & $\mathrm{x}$ & & & & Used to outline papers \\
\hline Hamblin & $\mathrm{x}$ & & $\mathrm{x}$ & & \\
\hline Invoyable & & & & $\mathrm{x}$ & Used to review \\
\hline Kline & $\mathrm{x}$ & $\mathrm{x}$ & $\mathrm{x}$ & & \\
\hline Vogel & $\mathrm{x}$ & & $\mathrm{x}$ & & Enjoyable to use \\
\hline Yao & $\mathrm{x}$ & & $\mathrm{x}$ & & \\
\hline
\end{tabular}

Table B-4. Study Guide Cons

\begin{tabular}{|c|c|c|c|c|c|}
\hline \multirow[b]{2}{*}{$\begin{array}{l}\text { Author of } \\
\text { Commentary }\end{array}$} & \multicolumn{5}{|c|}{ Cons of Study Guides } \\
\hline & Plagiarism & $\begin{array}{l}\text { Limits Critical } \\
\text { Thinking }\end{array}$ & $\begin{array}{l}\text { Incorrect } \\
\text { Information }\end{array}$ & $\begin{array}{l}\text { Missing important } \\
\text { information }\end{array}$ & Others \\
\hline Anonymous & $\mathrm{x}$ & $\mathrm{x}$ & $\mathrm{x}$ & & The plot information is minimal \\
\hline Dotzenrod & $\mathrm{x}$ & & & & \\
\hline Estrellas & & $\mathrm{x}$ & & & $\begin{array}{l}\text { Feelings of inferiority if the student's } \\
\text { analysis does not match the study } \\
\text { guide's }\end{array}$ \\
\hline Furchgott & $\mathrm{x}$ & & $\mathrm{x}$ & & Information is dated \\
\hline Gallagher & & & & & Original language of the text is lost \\
\hline Gorte & & & & $\mathrm{x}$ & $\begin{array}{l}\text { The emotional quality of the text is left } \\
\text { out }\end{array}$ \\
\hline Greatone1 & & & & $\mathrm{x}$ & \\
\hline Hamblin & & $\mathrm{x}$ & & & \\
\hline \multicolumn{6}{|l|}{ Invoyable } \\
\hline Kline & $\mathrm{x}$ & $\mathrm{x}$ & & & \\
\hline Vogel & & & & $\mathrm{x}$ & \\
\hline Yao & & & & $\mathrm{x}$ & \\
\hline
\end{tabular}




\section{APPENDIX C: SURVEY REFERENCES}

Anonymous, et al. "Teachers: How do You Know if Your Students Used SparkNotes?" Reddit, 26 Apr. 2014, www.reddit.com/r/Teachers/comments/2418k3/teachers_how_do_you_ know_if_your_students_used/. Accessed 25 Oct. 2018.

Dotzenrod, Nicole. "THE PAGE: Is SparkNotes just Cheating?" The Sun Chronicle, 24 Jan. 2012, www.thesunchronicle.com/features/the-page-is-sparknotes-just-cheating/article_ fff891ba-dfe0-59d9-abbc-74e10cb3c0a0.html.

Estrellas, et al. "Should I use SparkNotes?" College Confidential, 5 Aug. 2013, talk.college confidential.com/high-school-life/1537526-should-i-use-sparknotes.html. Accessed 25 Oct. 2018.

Furchgott, Roy. "A Professor Reviews CliffsNotes and Other Cheat Sheets." The New York Times, 15 Sept. 2010, www.nytimes.com/2010/09/16/technology/personaltech/16basics. html.

Gallagher, Kelly. "Why I have Brought SparkNotes into My Classroom. And Why You Should, Too." Kelly Gallagher, Gallagher \& Assoc, Inc., 30 Nov. 2014, www.kellygallagher.org/ kellys-blog/2014/11/30/why-i-have-brought-cliffnotes-into-my-classroom-and-why-youshould-too. Accessed 25 Oct. 2018.

Gorte, Mark. "The Pros and Cons of SparkNotes." DHS News, 6 Nov. 2011, update.dhs.mps.k12. mi.us/2011/11/the-truth-about-schmoop-and-sparknotes/.

Greatone1, et al. "SparkNotes in College=Bad Idea???" College Confidential, 9 Oct. 2008, talk. collegeconfidential.com/college-life/577748-sparknotes-in-college-bad-idea.html. Accessed 25 Oct. 2018. 
Hamblin, Larissa. "To The Students Who Think SparkNotes Is Enough." Odyssey, 13 Feb. 2017, www.theodysseyonline.com/students-sparknotes. Accessed 25 Oct. 2018.

Invoyable, et al. "Quick Check: CliffNotes vs SparkNotes?" College Confidential, 6 July 2008. talk.collegeconfidential.com/high-school-life/534149-quick-check-cliffnotes-vssparknotes.html. Accessed 25 Oct. 2018.

Kline, Diana. "My Generation Essay: SparkNotes: A Way to Cheat or Learn?" Pittsburgh PostGazette, 23 Dec. 2014. www.post-gazette.com/life/my-generation/2014/12/24/MyGeneration-Essay-SparkNotes-a-way-to-cheat-or-learn/stories/201412240072.

Vogel, Phil. "SparkNotes is a Valuable Resource for College Students." Lariat, Saddleback College, 14 Oct. 2013, lariatnews.com/opinion/sparknotes-is-a-valuable-resource-forcollege-students/.

Yao, Emily. "SparkNotes Useful Tool for Students.” The Oracle, Henry M. Gunn High School, 6 Dec. 2011, gunnoracle.com/1005/forum/sparknotes-useful-tool-for-students/. Accessed 25 Oct. 2018. 